\title{
WEBEROWSKA ZASADA WOLNOŚCI OD SĄÓW WARTOŚCIUJĄCYCH. INTERPRETACJA
}

Michał Kaczmarczyk

Uniwersytet Gdański

Mimo że na współczesnych uniwersytetach zasada neutralności światopoglądowej zdążyła stać się podstawą swobodnej pracy naukowej i profesjonalizmu uczonych, to mnożą się dziś wezwania do jej porzucenia. Dotyczy to zwłaszcza socjologii, która poszukuje możliwości wpłynięcia na rzeczywistość, a tym samym uzasadnienia własnej przydatności. Nawoływania do demaskacji fałszu „neutralności” przybierają różnoraka postać, pojawiają się pod dobrze znanymi hasłami „socjologii krytycznej”, „socjologii publicznej”, „socjologii zaangażowanej” czy „socjologii praktycznej”. Przynajmniej od czasu ukazania się często cytowanego artykułu Alvina Gouldnera Anty-Minotaur cayli mit socjologii wolnej od wartości (1984) głównym przeciwnikiem zwolenników „socjologii zaangażowanej” stał się Max Weber. To on właśnie zaczął być najczęściej utożsamiany z ideałem socjologii neutralnej, wyzbytej wrażliwości, wycofanej z życia publicznego, hołdującej mitowi biurokracji i zimnego profesjonalizmu. Wyważone komentarze uwzględniały fakt, że Weber nie sformułował zasady „wolności od wartości” w sensie braku wartości w nauce, a jedynie „wolności od sądów wartościujących" (Werturteilsfreibeit), uzupełnionej doktryną Wertbeziehung (odniesienia do wartości), dotycząca nieuniknionych związków między budowa teorii naukowej a wyznawanymi w danej kulturze wartościami (Sztompka 1975: 99-100). Dwie Weberowskie doktryny traktuje się jednak przeważnie odrębnie. Mówi się wtedy, że koncepcja Wertbeqiehung stanowiła postęp w socjologii wiedzy, a jednocześnie odrzuca się postulat Werturteilsfreiheit jako nieprzystający do socjologii społeczeństwa demokratycznego (Käßler 1997). Na potwierdzenie takiej częściowej akceptacji można przywołać stwierdzenia Webera, który sam uzasadniał 
wymóg wolności od sądów wartościujących między innymi sytuacją swej epoki, w której studenci zdani byli na profesorski monopol krzewienia wiedzy. Sam zwracał uwagę na „kult osobowości”, który zwiększal fascynację młodych ludzi jednostronnym przekazem: „Wydaje mi się, że [stawianie rzeczowego podejścia przed własną osoba] jest dziś bardziej pilne niż choćby czterdzieści lat temu, kiedy problem ten nie występował w tej formie" (Weber 1988c: 493-494)․․ Można dowodzić, że dzisiaj student ma w zwykłym telefonie dostęp niemal do całej wiedzy ludzkości, więc łatwo może skonfrontować opinie wykładowcy z innymi stanowiskami, nie wspominając, że sprawdzenie wiarygodności otrzymywanych informacji zajmie mu kilka sekund. Podlega dużo bardziej zróżnicowanym wpływom, a w warunkach ,gospodarki opartej na emocjach" wyrazista osobowość profesora może nie sprawiać większego wrażenia. Choć więc łatwo być dziś prorokiem na uczelni, to dużo trudniej znaleźć wiernych. Nie uległa jednak zmianie inna okoliczność podnoszona przez Webera, a mianowicie, podobnie jak na poczatku XX wieku brakuje dziś ludziom jasnych kryteriów rozstrzygania kolizji między różnymi wartościami, licznie reprezentowanymi w środowiskach akademickich. Niezwykle aktualna i jeszcze bardziej dotkliwa dziś niż wówczas jest też opisywana przez Webera relatywistyczna legitymizacja „wartościowań z katedry”. Weber pisał, że dawno przeminęło już przekonanie, jakoby ,jedno tylko z możliwych stanowisk w dziedzinie wartościowań praktyczno-politycznych musiało być etycznie słuszne” (Weber 1988c: 492) i że legitymizacja „kolorowego bukietu” wartościowań kulturowych pozostaje już tylko „prawo osobowości" nauczyciela (tamże).

Opisana sytuacja stanowi impuls do dokładnego zapoznania się z tym, w jaki sposób sam Weber uzasadniał postulat wolności od sądów wartościujących. Zgodnie z interpretacją, którą tu przedstawiam, postulat ten nie tylko nie stoi w sprzeczności z ideą Wertbeziehung, ale z niej wynika. Właściwa interpretacja wymaga wszak rekonstrukcji poglądów Webera zawartych w tekstach zebranych w tomie Gesammelte Aufsätze zur Wissenschaftslehre. Dwie prace, które poddaję dalej analizie, stanowią, moim zdaniem, spójną całość, choć każda z nich ma odrębną strukturę. Podążając za Weberem, podejmuję kolejno zagadnienia metody nauk społecznych, ich przedmiotu, zastosowań praktycznych i w końcu sensu nauki w ogóle. Staram się przy tym w jak najmniejszym stopniu posługiwać własnymi uprzedzeniami wynikającymi z obiegowych opinii na temat twórczości

\footnotetext{
1 Wszystkie cytowane teksty Webera pochodzą ze zbiorczego wydania pod redakcja Marianne Weber Gesammelte Aufsätze zur Wissenschaftslehre z roku 1922 (1988 [1922]).
} 
Webera. Proponowana tu interpretacja nie koncentruje się, tak jak wulgarna socjologia, na sytuacyjnych czy osobowych uwarunkowaniach idei Webera, lecz zmierza do zrozumienia tego, co Weber pragnął przekazać swoim czytelnikom i słuchaczom. Analiza omawianych tekstów skupia się na strukturze argumentów przytaczanych przez niemieckiego socjologa i związkach między poszczególnymi wątkami.

\section{/// I}

Praca Roscher und Knies und die logischen Probleme der historischen Nationalökonomie (Weber 1988a), opublikowana w postaci trzech artykułów w latach 1903-1906, formułuje podstawy metody historycznej w ekonomii i podejmuje dyskusję z przedstawicielami tzw. starej szkoły historycznej: Wilhelmem Roscherem i Karlem Kniesem. Krytyka dzieł tych autorów może być dziś odczytywana nie tylko jako opracowanie dotyczące teorii liczących sobie wówczas już kilkadziesiąt lat ${ }^{2}$, ale również jako wyrażone nie wprost stanowisko w debacie, która toczyła się we współczesnych Weberowi naukach społecznych. Przedstawiając swoje argumenty, dyskutuje on nie tylko z Roscherem i Kniesem, lecz także z pojedynczymi argumentami autorów takich jak psycholodzy Hugo Münsterberg, Theodor Lipps i Wilhelm Wundt czy socjolog Georg Simmel.

Punktem wyjścia tekstu Webera jest obserwacja dotycząca różnicy między dwoma typami nauk: ukierunkowanymi na formułowanie praw ogólnych (nomologicznymi) oraz obrazującymi rzeczywistość (idiograficznymi). Współcześni Weberowi niemieccy uczeni, tacy jak Wilhelm Dilthey, Wilhelm Windelband oraz Heinrich Rickert, którzy dokonywali tego rozróżnienia, starali się znaleźć dla niego uzasadnienie teoriopoznawcze i ontologiczne oraz ustalić zakres poszczególnych nauk historycznych i społecznych. Autor Etyki protestanckiej nie omawia jednak wyczerpująco prac wymienionych autorów, by skoncentrować się na myślach Roschera i Kniesa, u których znajduje, jak zobaczymy, wyraziste sformułowanie tez, w opozycji do których rozwija własną koncepcję nauk społecznych.

Krytyka poglądów Roschera kieruje się przede wszystkim przeciwko jego odziedziczonej po heglizmie tendencji do dedukowania faktów historycznych z systemu pojęciowego oraz traktowaniu społeczeństwa jako organizmu. Według Webera Roscher popadł w sprzeczność, przyrównując metodę historyczną do badań przyrodoznawczych i pisząc, że prawa

\footnotetext{
2 Omawiane prace Roschera pochodziły z lat 40. XIX wieku, a sam Roscher zmarł w roku 1894. Ostatnia książka Kniesa ukazała się w roku 1874, a jej autor zmarł w 1898 roku.
} 
naukowe, a więc to, co regularne i powtarzalne w danym zjawisku (das Gesetrmäßige), sa zarazem jego istotą (Weber 1988a: 7-9). Nie potrafił bowiem dostatecznie uzasadnić specyfiki postulowanej przez siebie metody historycznej, a formułując ją, odwoływał się do autorów bynajmniej jej niehołdujaccych, takich jak choćby Adam Smith. Regularności w wynikach obserwacji historycznych, powtarzanie się wzorców zachowań nie oznaczaja, że takie, a nie inne zachowania decyduja o charakterze społeczeństwa i jego rozwoju, że to one nadają mu sens.

Tym, co według Roschera pozwala stopniowo przybliżać się do odnajdywania istoty rzeczy w regularnościach obserwacyjnych, jest pojęciowe opracowywanie materiału historycznego. W wyjaśnianiu zjawisk kulturowych Roscher posługiwał się pojęciami zbiorowymi (Kollektivbegriffe). Wzorem było dlań zwłaszcza znane ze szkoły historycznej von Savigny’ego pojęcie „ducha narodu” (Volksgeist), którego emanacją miały być wszelkie szczegółowe zjawiska kulturowe (Weber 1988a: 10-11). Roscher wprowadził wprawdzie do własnej koncepcji większe zróżnicowanie, pisząc o różnych narodach, a nie tylko o jednym, w jego teorii jednak wszystkie one były poddane podobnym prawom, opierającym się na zaobserwowanych przez Roschera zbieżnościach rozwojowych. Weber zdecydowanie przeciwstawia się takiemu podejściu, będacemu w istocie dedukowaniem faktów z pojęć (tamże: 11-14). W świetle różnorodności historycznej jest ono nieuprawnione, niezależnie od tego, jak owe pojęcia zostały uzyskane. Według Webera obserwowane przez uczonych prawidłowości (w naukach przyrodniczych zyskujące prestiż praw przyrody) powinny być w dyscyplinach historycznych jedynie środkiem heurystycznym, służą wszak eliminowaniu, a nie poznawaniu tego, co indywidualne i szczegółowe. Opierające się na samej indukcji wyjaśnienia przyczynowe maja charakter redukcyjny w tym sensie, że eliminują z pola widzenia szereg tych aspektów badanych zjawisk, którym nie przypisuje się charakteru przyczyny bądź skutku. Innymi słowy, formułowanie praw w odniesieniu do historii nie jest pozbawione sensu, ale nie wystarcza do pełnego wyjaśnienia konkretnych zdarzeń.

Weber zarysowuje więc w dyskusji z Roscherem dwa modele budowy teorii naukowych w dziedzinie historii gospodarczej (dziś powiedzielibyśmy: historycznej socjologii gospodarki): model oparty na formułowaniu ogólnych praw metodą indukcyjną oraz model opisowy, każący poszukiwać znaczenia historycznego obserwowanych zbieżności (Weber 1988a: 13-15). Oba te modele, niezależnie od ich wad i zalet, przeciwstawia Weber modelowi, który odrzuca w całej rozciagłości, czyli dedukowaniu faktów historycznych z pojęć ogólnych (tamże: 15-16). Tymczasem właśnie 
zakładanie możliwości takiej dedukcji prowadziło Roschera w kierunku posługiwania się argumentami o proweniencji Heglowskiej w sytuacjach, gdy pozornie chodziło mu o empiryczne szukanie prawidłowości czy „systematykę pojęciową”. Roscher zbudował hierarchię pojęć i postulował równoległa do niej hierarchię faktów. Za przyczyny uważał to, co „ważniejsze”, za skutek to, co „mniej ważne”. „Stopień ważności” odpowiadał więc Heglowskiej „ogólności”. Jak pisze Weber, jedynie przywiązanie do tradycyjnej wiary religijnej powstrzymało Roschera przed zrównaniem „boskości” po prostu z najwyższym pojęciem (tamże: 20-22). Zamiast o „Bogu” twórca starej szkoły historycznej pisał więc o „ogólnym oglądzie", który miał nie tylko zawierać w sobie wszelką treść kulturowa, ale też stanowić wyznacznik badań historycznych. Problem w tym, że sam „ogólny ogląd” nie miał już żadnych kryteriów poprawności, a jego brak ugruntowania czynił historię irracjonalna.

Harmonijny obraz społeczeństwa jako jedności rządzącej się ścisłymi prawami wymagał nie tylko wyjaśnień statycznych, ale i praw dotyczących zmiany społecznej. Świadom tego wyzwania, Roscher stworzył odpowiednią teorię, według której dzieje każdego narodu podlegają tej samej sekwencji narodzin, dojrzewania i zaniku (Weber 1988a: 22-23). Kryła się za tym nie tylko cykliczna wizja historii, rodzaj metafizycznego historycyzmu, ale i organicystyczna wizja społeczeństwa, w którym wszystkie sfery życia podlegaja jednorodnemu procesowi przebiegającemu w tych samych fazach i w sposób wzajemnie uwarunkowany. Przykładem gospodarka, w której historii Roscher wyróżnił kolejno epoki dominacji natury, pracy i kapitału.

Ustosunkowując się do poglądu Roschera, Weber wskazuje na dwa możliwe sposoby wyjaśniania zmiany w naukach społecznych: jeden traktujący proces całościowy jako wynik procesów cząstkowych oraz drugi, emanatyzm, zgodnie z którym procesy cząstkowe stanowią realizację idei oddziałującej na rzeczywistość (Weber 1988a: 27-28). Krytyka, którą Weber formułuje pod adresem Roschera, nie dotyczy emanatyzmu jako takiego, ale raczej ukrycia emanatyzmu pod postacią organicyzmu. Wedle tej ostatniej koncepcji społeczeństwo nie jest po prostu agregatem jednostek, a gospodarka agregatem gospodarstw, lecz również „czymś więcej”, organizacja, całościa, której istota nie wyczerpuje się w procesach cząstkowych. Ów dodatkowy, wymagający wyjaśnienia element przejawia się w funkcjonowaniu konkretnych instytucji, które nie są wynikiem celowego działania zbiorowego, a mimo to przyczyniają się do stabilności i trwania całej gospodarki. Aby dostarczyć wyjaśnienia takich instytucji, Roscher przeszedł na inny poziom analizy i odwołał się do praw psychologii działania. Tymczasem 
Weber obiecywał sobie znaleźć u Roschera nieco inną woltę, a mianowicie próbę bardziej szczegółowego wyjaśnienia, a przynajmniej pojęciowego opracowania wzajemnych zależności między gospodarką a innymi dziedzinami życia, co oznaczałoby wyjście poza ekonomię rozumianą jako abstrakcyjne prawa dotyczące wyizolowanego aspektu działania i rozwinięcie tezy o „heteronomii ludzkiego gospodarowania” (Weber 1988a: 30). W tym kierunku poszła jednak dopiero młodsza szkoła historyczna - autorzy tacy jak Gustav Schmoller i Eduard Meyer.

Dodatkowa jakość „całości społecznej” nie znalazła wprawdzie wyjaśnienia na poziomie psychologii działania, lecz dała o sobie znać w postaci nowego dualizmu - z jednej strony, dążenia do dóbr tego świata (korzyści własnej), a z drugiej, „miłości Boga” przejawiającej się w ideach skromności, prawości, dobrotliwości, satysfakcji oraz wolności wewnętrznej. Według Roschera oba wymienione popędy mieszają się ze soba, przy czym miłość Boga w zależności od sytuacji w mniejszym lub większym stopniu kontroluje zmysł korzyści własnej. Ów boski pierwiastek zintegrowanych aktów woli miałby mieć tym większą siłę, im szerszy krag społeczny, do którego odnosi się w danym wypadku ,zmysł wspólnotowy". Im ten krag węższy, a więc na przykład im bardziej człowiek myśli o sobie i swej rodzinie, tym większy nacisk wywiera nań motyw korzyści własnej. Koncepcja ta, choć obiecująca, rozczarowała Webera brakiem empirycznego rozwinięcia. Roscher nie pokazał na przykładzie konkretnych instytucji, takich jak choćby giełdy i banki, w jaki sposób i czy w ogóle ludzkie działania kierują się dwoma rodzajami popędów. Udało mu się jedynie doprecyzować, że generalnie maja się do siebie jak środki i cele. Oznacza to, że, nieco podobnie jak głosiły optymistyczne filozofie nowożytności, Roscher uważał, iż w swej masie ludzie dbaja o własny interes, ale po to, by dzięki uzyskanym dobrom móc służyć innym i realizować swe szlachetne motywacje. W odróżnieniu od Roschera Bernard Mandeville wcale nie musiał odwoływać się do popędu miłości, aby wykazać, że prywatne przywary służą dobru publicznemu. Jeśli miał rację, podobnie jak idący mu w sukurs współcześni socjologowie David Caplovitz (1967) czy Raymond Boudon (2001: 93-117), to można obejść się bez dodatkowego czynnika postulowanego przez Roschera, by wyjaśnić zjawisko pozytywnych skutków postępowania egoistycznego. Przedstawiciel dawnej szkoły historycznej nie poszedł jednak tym tropem i to nie tylko ze względów religijnych, lecz, jak zwraca uwagę Weber, także dlatego, że lepsze rozwiązanie dostrzegł w organicyzmie. Według Roschera logice korzyści własnej wymyka się nie tylko oczywiste istnienie zmysłu wspólnotowego, objawiającego swe altruistyczne oblicze w sferze prawa 
i państwa, ale także całokształt stosunków gospodarczych, w którym, jak uważał, „przyczyna i skutek nie dają się od siebie oddzielić” (Weber 1988a: 34). Wyraźnie pobrzmiewa tu funkcjonalizm, czyli pogląd mówiący, że skutek jako stan zamierzony jest przyczyną tego, co do niego prowadzi. Jeśli jednak, jak pisze Weber, wszystko w gospodarce istnieje ze względu na swą funkcję, to z błędnego koła wyjaśnień wyprowadzić może jedynie odwołanie się do większych całości, a ostatecznie do „organicznego życia całego kosmosu” (Weber 1988a: 34). Wszystko, o czym pisze Roscher, pojawia się więc na tle czegoś, co stanowi jego niewyjaśniona podstawę. Podstawę tę można jedynie różnie identyfikować, ale nie można jej uniknać, ponieważ prędzej czy później napotyka się barierę irracjonalności. Tej ostatniej zaś z natury rzeczy nie można ani wyjaśnić, ani ująć w formie praw nauki, toteż występuje ona w koncepcjach funkcjonalistycznych pod postacią innych pojęć. U Roschera jest to „jedność” - jedność powiązań historyczno-społecznych, która jako obiekt poznawczy wymyka się naukowemu wyjaśnieniu.

Mogłoby się wydawać, że nie ma nic złego w określeniu granicy poznania jako granicy wyjaśnień funkcjonalnych. Na pierwszy rzut oka widać jednak wyraźnie, że jeśli postąpimy tak jak Roscher i powiązania funkcjonalne uznamy nie tylko za źródło wyjaśnień, ale i racjonalności w ogóle, to irracjonalność ostatecznego układu odniesienia prowadzi do wniosku o irracjonalności niższych poziomów. Jakże bowiem może być sensowne dążenie do czegoś, co samo w sobie jest pozbawione sensu? W tym właśnie kierunku zmierzają uwagi krytyczne Webera, który pisze, że samo rozpoznanie „heteronomii” gospodarki świadczy o tym, że zadaniem starań polityki gospodarczej nie może być samo „zwiększanie bogactwa narodowego" (Weber 1988a: 37). Ponadto wszelkie normy formułowane przez naukę o gospodarce są zawsze względne wobec poziomu rozwoju, na jakim znajduje się w danym momencie społeczeństwo (zgodnie z Roscherowskim cyklem rodzenia się, dojrzewania i zaniku). Nikt nie jest w stanie sformułować ideałów ogólnie obowiązujących, a co najwyżej wskazówki dla ludzi określonego czasu i miejsca, w ograniczonym układzie odniesienia. W tym sensie wszelkie wartościowania musza pozostać subiektywne. Zarazem jednak warunki lokalne pozwalaja, przynajmniej czysto teoretycznie, formułować obiektywne wymogi „właściwego dopasowania” czy „stanu normalnego”, a zadania tego ekonomista może podjąć się wobec gospodarki tak samo, jak lekarz wobec organizmu. Dlatego też funkcjonalizm, mimo swego relatywizmu, nie zakazuje wcale 
formułowania sądów wartościujących ${ }^{3}$. Czy jest on jednak w stanie pyta Weber - stwierdzić, na jakim etapie rozwoju rzeczywiście się znajdujemy? Czy nasz naród znajduje się w fazie narodzin, dojrzewania czy może zaniku? Sam Roscher przyznawał, że nie można tego określić, ale widział w tym raczej korzyść niż fatalne ograniczenie. Według Roschera brak wiedzy o „godzinie śmierci” uszczęśliwia ludzi, zwłaszcza polityków, którzy działaja pełni optymizmu i ze słusznym przekonaniem, że „rzeczywiste potrzeby narodu" (wymogi czasu) przejawią się w działaniach społecznych (ujętych statystycznie - wszak Roscher, podobnie jak później Durkheim, wierzył w metafizyczną siłę statystyki). Tym samym, wedle Roschera, normy słusznego postępowania i wartościowania są „zapisane” w społeczeństwie, trzeba je jedynie właściwie zinterpretować w świetle ogólnych praw ekonomicznych. Ludzie są w swej masie nośnikami niezmiennego systemu norm danych przez Boga.

Nietrudno odczytywać Weberowską krytykę metody historycznej Roschera jako odnoszącą się także do innych odmian funkcjonalizmu w socjologii. Wyjaśnienia funkcjonalistyczne, integracja orientacji wartościujących, definicja wartości jako potrzeb wyższego rzędu czy wreszcie metodologiczna zasada układu odniesienia to wątki występujące przede wszystkim w teorii Talcotta Parsonsa, który mimo szerokich odniesień do dzieła Webera w swej The Structure of Social Action (1937|1968) pominą wątek Weberowskiej krytyki pod adresem Roschera, a w kolejnych pracach podążył raczej śladami Émila Durkheima niż Webera. Nie bez powodu Parsonsowska koncepcja społeczeństwa nowoczesnego do dziś uważana jest niemal za „typ idealny” ukrytego wartościowania (mam na myśli zwłaszcza krytykę ze strony Alvina Gouldnera).

Z kolei u Émila Durkheima możemy znaleźć zarówno wspomniany wcześniej organicyzm, jak i dualizm ludzkich popędów i nieco inaczej niż u Roschera ujętą ideę wzrostu moralności wraz z rozszerzaniem się kręgu społecznego. Durkheim, podobnie jak Roscher, nie wzdraga się przed formułowaniem sądów wartościujących, są dla niego konsekwencja poznania społeczeństwa: „Moralność zależy od społeczeństwa, nie ode mnie" (Durkheim 1976: 116). W konsekwencji zarówno wobec Durkheima, jak i Parsonsa można podnieść ten sam zarzut, który Weber stawia Roscherowi pod koniec dyskusji z jego dziełem. Skoro ludzkie motywacje ulegaja stałemu dopasowaniu do aktualnych (na danym poziomie rozwoju) wymogów trwania organizmu społecznego, to czy może pojawić się wśród ludzi autentyczny i zasadny sprzeciw wobec otaczającego świata?

${ }^{3}$ Charakterystycznym przykładem socjologia Durkheima. 
Jak jest możliwe przeciwstawienie się historii, przeciwstawienie nowych wartości starym i wreszcie osobista, niezapośredniczona społecznie religia, niebędąca wyrazem „ogólnego oglądu” z punktu widzenia społeczeństwa jako całości? Jak pisze Weber: „Naprawdę poważne i trwałe konflikty między zrządzeniami losu niesionymi przez historię a zadaniami życiowymi, które Bóg stawia ludziom i narodom, okazują się niemożliwe, jednostka w ogóle nie może postawić sobie zadania autonomicznego określenia swych ostatecznych ideałów" (Weber 1988a: 40).

\section{// / II}

W dyskusji z Kniesem Weber odnosi się, podobnie jak w wypadku analizy tekstów Roschera, do błędów typowych nie tylko dla tego autora, ale dla większej formacji intelektualnej, która odrodziła się na przełomie wieków jako ruch tak zwanych „socjalistów z katedry”. Wyjściowym tematem tekstów poświęconych Kniesowi jest pozycja ekonomii politycznej wśród innych nauk i pytanie, czy bliżej jej do nauk przyrodniczych, humanistycznych, czy historycznych. Punkt wyjścia jest więc podobny jak w dyskusji z Roscherem, choć od początku przeciwstawienie nauk opartych na formułowaniu praw i opisywaniu faktów zostało osłabione przez wprowadzenie trzeciej kategorii, czyli nauk dotyczących „ducha”, a więc badających motywy działań i zarazem uwzględniających zewnętrzne warunki ludzkiego postępowania. Adekwatne wyważenie proporcji między elementami działania miało rozstrzygnąć o ostatecznym zaklasyfikowaniu ekonomii politycznej do określonej grupy nauk.

Takie zakreślenie tematu dało Weberowi pole do wnikliwych rozważań na temat pojęcia działania. Także tu rozpoczą od polemiki z Kniesem, przy czym zauważył, że sposób, w jaki Knies pojmuje działanie, wyraźnie nawiązuje do problemu, przed jakim ostatecznie stanął Roscher, i w tym sensie pozwala na kontynuację argumentacji rozwijanej w dialogu z Roscherem. Jak wspomniałem, w ramach swojego zamkniętego systemu pojęciowego Roscher nie potrafił uzasadnić choćby możliwości sprzeciwienia się człowieka zastanej rzeczywistości historycznej i jej prawom w jakikolwiek inny sposób niż przewidziany przez same te prawa. Innymi słowy, konstruując swą teorię, Roscher nie wyposażył człowieka w wolność, a tym samym popadł w rodzaj panlogistycznego determinizmu. Nawet jednak porzucenie Heglowskiego kostiumu nie anulowałoby problemu, wszak prawa przyczynowe oparte na wiedzy indukcyjnej także zdaja się nie pozostawiać miejsca dla autonomicznych wyborów moralnych. Problem ten dobrze rozumiał Knies, ponieważ działanie to dla niego 
wypadkowa ludzkiej wolności oraz „elementu konieczności”, na który składają się uwarunkowania naturalne oraz „siła wzajemnych zależności społecznych". To, co konieczne, daje się według Kniesa, podobnie jak według Roschera, poddać racjonalnej analizie i ująć w konieczne prawa, ilekroć prawidłowość każe wnosić o istnieniu związku przyczynowego. Co jednak począć z elementem wolnej woli? Wola nie może być racjonalna, jeśli nie wykazuje regularności, a jeśli je wykazuje, daje się przecież wyjaśnić przyczynowo. Ceną akceptacji istnienia wolnej woli okazuje się negacja ludzkiej racjonalności. Racjonalne mogą być według Kniesa tylko prawa rządzące tym, co się powtarza i daje przewidywać, człowiek jest zaś nieprzewidywalny jako indywiduum i tenże element nieprzewidywalności powinna, według niego, brać pod uwagę ekonomia polityczna formułująca prawa działań ekonomicznych.

Podejmując polemikę z Kniesem, Weber rozpoczyna od oczywistej niewiarygodności koncepcji Kniesa na poziomie zjawiskowym (1988a: 45). Zwraca uwagę, że nie postępowanie człowieka, lecz właśnie indywidualne i niepowtarzalne warunki przyrodniczo-historyczne są czynnikiem, który uniemożliwia formułowanie ogólnych praw ekonomii. Zasadnicza część argumentacji Webera wymierzona jest jednak w utożsamienie wolności i irracjonalności. Jedynie stnowisko akceptujące zarazem wolność i racjonalność człowieka czyni samodzielną naukę o działaniu czymś sensownym, gdyby wszak człowiek był irracjonalny, to wszelkie jego indywidualne decyzje należałoby traktować jako zwykłe odchylenia od praw przyrody.

Podejrzenia Webera wzbudza od początku pojęcie „irracjonalności”, które niekiedy nabiera pozytywnego zabarwienia, znacząc coś więcej niż po prostu „brak zdolności do podejmowania racjonalnych decyzji”. Dzieje się tak wtedy, gdy utożsamiane jest z „kreatywnością”, a więc tworzeniem czegoś nowego i wartościowego, ale niemożliwego do przewidzenia (1988a: 45-49). Chodzi w szczególności o przypadki, gdy kreatywność wynika ze szczególnej kombinacji cech określonej osoby, a więc z jej „osobowości”. Czymże jednak jest „osobowość”? Weber uważa, że nie można odpowiedzieć na to pytanie, podając taką czy inną cechę samej osoby, którą określamy za pomocą tego pojęcia, podobnie jak nie możemy w taki sposób określić kreatywnego dzieła. To, czy coś nazywamy kreatywnym, a kogoś „osobowością”, zależy raczej od nas - od szczególnego zainteresowania okazywanego pewnym osiagnięciom czy osobom lub od znaczenia, jakie w danych warunkach historycznych przypisuje się działaniom określonych jednostek jako czynnikom sprawczym „ważnych” zmian. „Osobowośćc” jest więc pojęciem względnym i zależy od tego, co Weber, a za nim między innymi Jürgen Habermas, nazywał interesem poznawczym 
(Erkenntnisinteresse) (1968). Względny charakter pojęcia nie oznacza jednak, że sprawstwo przypisywane osobowościom nie podlega prawom przyczynowym i nie jest stwierdzalne tak samo jak inne zdarzenia, którymi zajmują się nauki przyrodnicze. Weber dowodzi, że w procesie naukowego wyjaśniania ludzkich działań interesy poznawcze nie tylko skłaniają nas do zainteresowania się danym zachowaniem jako obserwowalnym zjawiskiem, ale stanowią motyw do poszukiwania coraz głębszych wyjaśnień, a więc przyczyn o coraz bardziej nieuchwytnym charakterze. Po pierwsze, jak wspomniałem, interes poznawczy pozwala nam zidentyfikować konkretne działanie jednostki w jego specyfice i przyczynowej jedności. Po drugie, każe poszukiwać odpowiedzi na pytanie, co skłoniło jednostkę do danego zachowania, a więc kręgu możliwych impulsów zewnętrznych, przemyśleń, skłonności, czyli motywów. Po trzecie, zrozumienie konkretnego motywu każe pytać o specyfikę motywów, które się powtarzają, stałych źródeł nie tylko jednego działania, ale sposobu życia w danych okolicznościach historycznych. Po czwarte, istnienie w jednostce trwałych tendencji nasuwa myśl o sprzyjającym im podłożu psychiczno-środowiskowym, wyposażeniu genetycznym, sposobie wychowania itd. Weber szkicuje sposób przyczynowego wyjaśnienia każdego ludzkiego działania, także pozornie irracjonalnego. Natomiast irracjonalność nie stanowi dlań czynnika wyjaśniającego, choć gdy kryje w sobie znaczenie „kreatywności” bądź „osobowości”, może być przejawem interesu poznawczego.

Przykładem autora, który „kreatywność” traktuje jako rzeczywista cechę ludzkiego umysłu, wynikająca z „wzajemnego oddziaływania elementów psychiki”, jest dla Webera Wilhelm Wundt, słynny niemiecki psycholog, który uważał, że w procesie rozwoju ludzkiej psychiki powstaja nowe wartości - jakości, których w początkowych fazach procesu w ogóle nie było (Weber 1988a: 49-61). Moc sprawczą przypisywał przy tym nie poszczególnym elementom psychiki, lecz ich wzajemnym oddziaływaniom, prawu, które określał jako „prawo wzrostu energii psychicznej" i porównywał do fizycznego prawa zachowania energii. Wundt uważał, że sąd czy wnioskowanie zawierają więcej niż poszczególne wyobrażenia, które się na nie składają nie są więc „agregatami wyobrażeń". Weber dowodzi, że rozumowanie Wundta opiera się na nieświadomym wartościowaniu cech działań w odniesieniu do ich przyczyn lub skutków. Zwraca uwagę, że naddatkiem osiąnięć psychiki, niezawartym w samych częściach składowych, jest znaczenie, które przypisuja tym osiagnięciom badacze, a często sam człowiek i kształtująca go kultura. Wartościowaniom podlegaja jednak nie tylko zjawiska psychiczne, lecz także przyrodnicze. Są tu tak samo podobne jak w tym, że podlegaja 
identycznym prawom przyczynowym. Zastępowanie jednak wyjaśnień przyczynowych wartościowaniem sprawia, że uczony bierze własne życzenia za rzeczywistość.

Argument Webera przeciwko Wundtowskiemu „prawu wzrostu energii psychicznej” wiąże się z koniecznością wyjaśnienia, w jaki sposób „energia psychiczna” rośnie mimo śmierci ludzi lub zaburzeń w funkcjonowaniu ich mózgu. Według Wundta stały jej wzrost jest możliwy dzięki temu, że ustanie indywidualnego życia psychicznego może zostać zrekompensowane przez zbiorowość, do której należy dana jednostka, i że ów stosunek kompensacji można również odnotować w stosunku między narodami a ludzkością. Jak jednak zauważa Weber, zasada „kompensacji” wymaga podmiotu i wywołuje wattpliwość, wobec kogo ta zasada obowiązuje. Czy, jak pyta ironicznie Weber, śmierć Cezara zostanie zrekompensowana samemu zmarłemu, rodzinie, która po nim pozostała, kandydatom do jego urzędu, boskiej Opatrzności czy może psychologistycznemu metafizykowi? (Weber 1988a: 55-56). Jedyna sensowna odpowiedź musi wskazywać na „postęp ludzkości” jako kryterium określania wartości rekompensaty, a także jako punkt wyjścia rozważań o „kreatywnej syntezie”.

Krytyka Wundta pozwoliła Weberowi dostrzec, że prawdziwie empiryczna psychologia musi wyrzec się wartościowań ukrytych pod pozorami argumentacji przyczynowej, w szczególności zaś w pojęciach ogólnych zaczerpniętych z życia codziennego, ale zrozumiałych tylko w kontekstach metafizycznych. Najważniejszy wszak wniosek płynący z analizy poglądów Wundta dotyczy specyfiki łańcuchów przyczynowych. Są one mianowicie zawsze równoważne, to znaczy w powiązaniach przyczynowo-skutkowych każdy element jest równie ważny w tym sensie, że każdy jest w podobny sposób konieczny do pojawienia się jego skutku. We współczesnej nauce różnicuje się, rzecz jasna, rangę przyczyn, mówiąc o warunkach wystarczających i koniecznych, a także, jak zaproponował John Leslie Mackie (1965), o niewystarczających, lecz koniecznych składowych warunków, które same nie są konieczne, ale wystarczające dla pojawienia się skutku. Zwarcie w instalacji elektrycznej nie jest na przykład koniecznym warunkiem pożaru, bo co innego może wywołać pożar, ale nie jest też wystarczające, wszak aby spowodowało pożar, musi być spełnionych wiele innych warunków. Niemniej wyjaśniając konkretny pożar, możemy określić jego przyczynę jako określoną kombinację warunków niekoniecznych, acz wystarczających (np. łatwopalne materiały budowlane), pośród których jeden (np. spięcie instalacji elektrycznej) miał charakter niewystarczający, lecz konieczny. Waga poszczególnych elementów składających się na przyczynę jest równa. Jednocześnie określając możliwe przyczyny pożarów 
w przyszłości, możemy zakreślić dzięki zebranym doświadczeniom szersze spektrum warunków, które nie są konieczne, ale wystarczające, o ile pojawi się także warunek konieczny. Możemy też na podstawie wnioskowań statystycznych określać wagę każdego z warunków z punktu widzenia możliwości pojawienia się pożaru. Tym, co wprowadza nierównowagę do naszego rejestru możliwych warunków, nie jest jednak sama statystyka, lecz nasz interes w zapobieganiu pożarom, który znajduje następnie wyraz w interesie poznawczym. Każdy z warunków daje się rozkładać na kolejne elementy składowe, którym przypisywać możemy większą lub mniejszą wagę. Jedynie interes uczonego każe widzieć większe całości i konkretne związki w nieskończonych łańcuchach przyczyn i skutków.

Powyższe refleksje nie powinny prowadzić do wniosku, że o prawdziwości poznawczej decyduje wartość praktyczna danego prawa nauki. Jest raczej tak, że wyraźne praktyczne niepowodzenie może świadczyć o nieprawdziwości teorii leżącej u jego podstaw, ale sama wartość celu, który nam przyświeca, nie może zostać wykazana naukowo, o ile nie powrócimy do problematycznych idei wyprowadzających moralność ze stanu systemu społecznego. Nawet jednak gdyby całkowicie oderwać naukę od praktycznych wartości, do których realizacji jest zaprzęgana, uczeni nie będą mogli uchylić się od odpowiedzi na pytanie, na czym polega wartość samego poznania naukowego (Weber 1988a: 61). Co więcej, suwerenność poznawczej wartości nauki można łatwo rozpoznać w empirycznej niesprawdzalności założeń, jakimi sa prawa matematyki i logiki. Podobnie jak autoteliczna wartość poznania naukowego świadczą one o niemożliwości redukcji prawdy naukowej do „wymogów dnia”. Poza tym teleologiczne konstrukcje opierające się na przykład na teoremacie „prawa dopasowania” można łatwo zredukować do praw przyczynowych ukazujących dopasowanie jako serię reakcji (Abell 1975: 157-159).

Wiedząc już, że w nauce, w tym zwłaszcza w naukach społecznych, badania przyczynowe ukierunkowane sa niechybnie przez interesy poznawcze, możemy zapytać o źródło samych tych interesów. Czy nie podlegaja one podobnemu wyjaśnieniu przyczynowemu jak „dopasowanie"? Weber rozpatruje to pytanie jako problem genezy wartości, wszak to wartości właśnie leżą u podstaw interesów poznawczych, to za sprawą wartości nadajemy pewnym rzeczom większe znaczenie niż innym. Jeśli jednak przejmujemy wartości od innych: rodziny, wspólnoty, kultury swej epoki, to czy nie rządzą wartościami prawa społeczne, mówiące na przykład o podziałach i konfliktach społecznych? Jak zobaczymy, jedna z głównych socjologicznych tez Webera mówi o niepełnej jedynie strukturalnej determinacji wartości. O ile więc nie możemy wyjaśnić 
wartości przyczynowo, o tyle nie możemy inaczej rozumować przyczynowo, niż kierując się wartościami, wszak nieskończone łańcuchy przyczynowo-skutkowe nabierają sensu dopiero dzięki wartościom wydobywającym pewne ich segmenty i syntetyzującym je w większe całości. Nie oznacza to jednak w żadnym razie, że sama przyczynowość w świecie podlega ingerencji wartości, w tym sensie, że wartości, na przykład przez działanie Boga czy człowieka, zmieniaja coś w łańcuchach przyczynowo-skutkowych. Takie myślenie sprzyja nie tylko wierze w postęp ludzkości, ale też zaburza poprawność poznania naukowego. Jego źródeł upatruje Weber w filozofii Kanta i jego słynnej formule „przyczynowości poprzez wolność" (1988a: 62). Miała ona, zdaniem Webera, zgubny wpływ na nauki o kulturze, które myśl Kanta zainspirowała do tego, by „świat rzeczy samych w sobie" wplatać w rzeczywistość empiryczną lub postulować siły sprawcze rządzące się całkiem odrębna przyczynowością. Choć więc, podkreślmy, ani metafizyka, ani naturalizm nie powinny zgłaszać roszczeń do pełnego zrozumienia świata, to nie powinny być też ze sobą mieszane.

Po rozważeniu pojęć „kreatywności” i „osobowości” Weber przechodzi do analizy ,irracjonalności” ludzkiego działania w znaczeniu zwykłej nieprzewidywalności. Czyni to, by zastosować swą koncepcję ontologicznego uniwersalizmu zasady przyczynowości do działania i tym samym wykazać nieprawdziwość tezy Kniesa (Weber 1988a: 64-66). Także w ramach tej polemiki rozpoczyna od poziomu zjawiskowego, by przejść na poziom motywacji, a na koniec na poziom zasad metodologicznych. Pisze więc najpierw, że już w rzeczywistości naszych przeżyć nie może być mowy, że człowiek jest generalnie nieprzewidywalny. Każdy rozkaz, tak jak każde prawo uchwalane przez parlament, opiera swe istnienie i swą skuteczność na założeniu, że w przeważającej masie przypadków znajdzie posłuch. Nie byłoby to możliwe, gdyby rozkazodawcy i prawodawcy nie byli w stanie przewidywać ludzkiego postępowania. Nie istnieje w tym sensie zasadnicza różnica między zjawiskami świata przyrody i świata ludzkiej psychiki. Fakt, że czyjeś zachowanie jest nieprzewidywalne, nie oznacza, że jest niepojmowalne, że nie można go wytłumaczyć za pomoca praw psychologii empirycznej. Brak sprzeczności z wiedzą nomologiczna oznacza zatem, że nie mamy prawa do orzekania nieprzewidywalności człowieka. Nieprzewidywalność dotyczy zresztą, być może w większym stopniu niż człowieka, świata przyrody. Jakże często uczeni spotykają się w nim z anomaliami. Nie odwodzą ich one jednak zwykle od prowadzenia badań, przeciwnie - zachęcają do poszukiwania wyjaśnień, rodzą interesy poznawcze. 
Polemika z tezą o nieprzewidywalności dała Weberowi asumpt do sformułowania założenia, że ludzkie działanie nie jest mniej, ale bardziej przewidywalne niż zdarzenia w świecie przyrody. Moga być bowiem nie tylko wyjaśniane przyczynowo ze względu na prawidłowości zachowań poddawanych obserwacji, ale też sa zrozumiałe dla uczonego, który sam jest podmiotem działającym i potrafi sobie wyobrazić, „przeżyć ponownie" (nacherleben) to, co zachodzi w psychice obserwowanego (Weber 1988a: 68-70). Ta możliwość sensownej interpretacji jest pomocna w dwójnasób. Po pierwsze, pozwala poznać motywy, sens działania, a po drugie, daje możliwość zwrócenia uwagi na możliwe przyczyny wystapienia określonego motywu, a także możliwe skutki, na przykład sekwencje kolejnych działań. Gdy obserwujemy kogoś, kto rozkłada przed sobą codziennie słownik języka niemieckiego, możemy się domyślić, że przyczyną tego jest coś, co skłania tę osobę do nauki języka, zawężamy więc znacząco krąg przyczyn, który będzie wchodził w grę w dalszym wyjaśnianiu. Ta metoda badawcza, zwana „rozumieniem”, tak oczywista, bo przecież stosowana przez każdego (nie tylko badacza społecznego), charakteryzuje się wieloma odmiennościami od metody indukcyjnej. Przede wszystkim nie pozwala na sformułowanie praw koniecznych, a jedynie wskazuje na możliwość zachodzenia pewnych przyczyn, na wyższe ich prawdopodobieństwo. Poza tym ma charakter pozytywny, pozwala rozpoczać poszukiwanie przyczyn od określenia konkretnego motywu czy stanu psychicznego, podczas gdy wiedzę nomologiczną często buduje się na poszukiwaniu przyczyn droga eliminacji, na przykład odpowiadając na pytanie, co może być w rzutach kostką przyczyną ciagłego odchylenia wyników od średniej. Trzecia szczególna cecha rozumienia to proporcjonalność wzrostu jego trafności do wzrostu racjonalności badanego działania. Gdy znamy czyjeś wartości i cele, to łatwo nam pojąć, dlaczego postępuje tak a nie inaczej, jeśli to postępowanie służy realizacji owych wartości i celów. Jeśli jednak działanie danej osoby zupełnie odbiega od założonych celów, nie tylko nie możemy tej osoby „zrozumieć”, ale poszukujemy odpowiednich praw psychologii czy medycyny, które pozwoliłyby nam pojać, dlaczego dana osoba jest nieracjonalna. Rozumienie wymaga więc często odwołania się do wiedzy nomologicznej, podobnie jak ta ostatnia często korzysta z interpretowalności działania.

Postulat stosowania metody rozumienia, jakkolwiek oczywisty z punktu widzenia wartości poznawczej, rodzi trudne pytanie o obiekt poznania nazywanego rozumieniem, a tym samym o rzeczywistość, która zajmuja się nauki o działaniu. Wydaje się narzucać taka odpowiedź na to pytanie, która bliska byłaby właściwej definicji „irracjonalności”, 
jakże niejasno określonej przez Kniesa. Można mianowicie sądzić, że owa rzeczywistość wewnętrzna, podlegająca „rozumieniu”, jest nieredukowalna do rzeczywistości przyrody i w tym sensie ,irracjonalna”. Aby ustosunkować się do tego stanowiska, Weber podejmuje polemikę z psychologiem niemieckim Hugonem Münsterbergiem (1988a: 71-82). Pisał on, że „Ja" przeżywające świat nie może samo być obiektem wyjaśnień operujących pojęciami i prawami, wszak nigdy nie jest nam dane w taki sposób jak nasze otoczenie i nie daje się opisać. Podobny charakter ma jego „przeżywany świat”, wszak „Ja” nie tylko postrzega, ale również ocenia, wartościuje, czyli, krótko mówiąc, ustosunkowuje się do świata będącego dla niego przestrzenią wartościowania. Dopiero pomyślenie świata jako odrębnego obiektu w celu jego wyjaśnienia czyni z niego postrzegalny związek faktów. Weber zauważa, że zgodnie z tą koncepcja w świecie przeżywanym nie ma miejsca na racjonalne działanie, gdyż kategorie celu i środku wymagaja „zobiektywizowania” świata i potraktowania go jako dziedziny zjawisk przyczynowych, wymagaja zatem reguł doświadczenia. W wirtualnym dialogu, bo prowadzonym przez Webera $\mathrm{w}$ istocie $\mathrm{z}$ wyobrażonym partnerem, Münsterberg odpowiada, że obiektywizacja świata w celu jego poznania wyrasta ostatecznie z owego działania racjonalnego, które tworzy dla świata przeżywanego podbudowę w postaci kosmosu „doświadczenia”, aby wzmocnić nasze „oczekiwanie” przyszłości przez możliwość ustosunkowania się do owego kosmosu. „Doświadczenie” leżące u podstaw nauk obiektywizujących możliwe jest wszakże dopiero za sprawą oderwania się rzeczywistości od aktualności tego, co naprawdę przeżywane. Tym samym pozostaje zawsze nierzeczywistym produktem abstrakcji, który służy celom praktycznym. W konsekwencji aktualna wola nigdy nie jest przeżywana tak samo jak jej obiekty, które uświadamiamy sobie jako przedmioty nauk obiektywizujących, a więc odmiennie niż „dane początkowo” (vorgefunden) treści doświadczenia. Ustosunkowując się do tego argumentu, Weber wprowadza rozróżnienie między „,istnieniem” a „sądem egzystencjalnym”, który może dotyczyć każdego obiektu, w tym i konkretnej, własnej woli. Istnienie woli, a więc także fakt, że jest „przeżywana”, jest czymś innym niż wiedza o „przeżyciu”. Münsterberg odpowiedziałby na to, zdaniem Webera, wskazując na introjekcję sfery psychicznej do ciała, a więc obiektywizację świata jako warunek tego, by wola mogła stanowić przedmiot opisu i wyjaśnienia. Tymczasem, według Münsterberga, człowiek wie także o swej rzeczywistości przeżywanej, a więc o sobie jako istocie nieprzerwanie wartościującej, o swym „świecie wartości”. Münsterberg wyraźnie przeciwstawia ten świat oderwanej od niego obiektywizacji 
wytwarzającej przedmioty „wolnego od wartości” poznania analitycznego. Określa też świat wartości jako sferę wolności ludzkiej, a świat zobiektywizowany jako sferę determinizmu.

Z punktu widzenia Webera przewaga Münsterberga nad Kniesem polega na tym, że ten pierwszy nie przeciwstawia sobie racjonalnych i irracjonalnych uwarunkowań działania, lecz dwa różne sposoby oglądu rzeczywistości: subiektywizujący i obiektywizujący, jeden stale ujmujący rzeczywistość jako wartościowaną przez podmiot oraz drugi, systematycznie abstrahujący od „Ja". Błędem Münsterberga było jedynie wyłączenie wszelkiego myślenia subiektywizującego spod działania praw przyczynowych. Wniosek ten prowadziłby bowiem do niemożliwości naukowych badań motywów działań, o ile tylko chcielibyśmy prawa przyczynowe zastosować do wiedzy uzyskanej droga rozumienia. Weber nie widzi tymczasem żadnego logicznego powodu, aby wyciagać taki wniosek. Twierdzi, że treść świadomości ludzkiej jest niezwykle złożona, co nie pozwala na jej rozłożenie na czynniki pierwsze (proste odczucia), a historia zależności między religią a gospodarką musi badać właśnie złożone całości przekonań, odczuć i nawyków w ich rozległych powiązaniach z rzeczywistością zewnętrzna. Historia w żadnym razie nie dotyczy jedynie „strony wewnętrznej”, a jeśli przyjmuje perspektywę subiektywizująca, to odnosi ja do zewnętrznych impulsów, zachęt, dokonań i warunków. Polemika z Münsterbergiem pozwoliła więc Weberowi dookreślić zasadę rozumienia jako przyjęcia punktu widzenia podmiotu, który nie tylko poznaje świat, ale przeżywa go, wartościująco się doń ustosunkowując. Psychologia nie może abstrahować od tej zależności od „Ja”, ale w niczym nie zmienia to faktu, że nie można dowolnie żonglować przyczynowością, rezerwując ją tylko dla pewnych obszarów rzeczywistości. O tym, w jakim zakresie dane działanie może zostać wyjaśnione „rozumiejąco”, a w jakim trzeba odwołać się do wiedzy nomologicznej (psychiatria, biologia, fizyka, ale także ekonomia i psychologia w stopniu, w jakim są naukami nomologicznymi), decydować może tylko konkretny przypadek. Ostatecznie będzie o tym decydować punkt widzenia określony przez interes poznawczy. Ten punkt widzenia wyznacza pole zainteresowań badawczych i krag uwarunkowań, które będą wchodzić w grę w wyjaśnieniu działania. Historia nie musi na przykład zawsze odwoływać się do psychologii, a psychologia na przykład do biologii. Historia nie zajmuje się przecież życiem psychicznym ludzi, lecz człowiekiem w jego zmieniającym się stosunku do świata. Nie każda grupa uwarunkowań będzie więc miała jednakowe znaczenie przy prowadzeniu studiów, a jedynie taka, która jest problematyczna ze względu na cele poznawcze. Tak na przykład historia czarnej 
śmierci w Anglii może wykorzystywać zarówno wiedzę bakteriologiczna, psychologiczną, jak i wiedzę o kulturze epoki, ale jeśli aspekt biologiczny tej historii zostanie potraktowany jako przypadkowa okoliczność, nie będzie to wcale błędem z punktu widzenia interesu poznawczego historyka, który chce zrozumieć działanie ludzi w tamtym czasie, aby wyjaśnić (przyczynowo!) fakty historyczno-kulturowe.

Jeśli wyniki statystyk albo pojęcia psychologiczne nie są możliwe do „zinterpretowania” za pomocą wewnętrznej rekonstrukcji, „rozumienia”, to, jak pisze Weber, „przedstawiaja prawdy, które brane są przez historię jako «dane», ale nie wnosza nic do zaspokojenia specyficznego «interesu historycznego»” (1988a: 84). Weber wyniósł więc metodę „rozumienia" w naukach społecznych i naukach o kulturze do rangi podobnej, jaka metoda indukcyjna zajmuje w naukach przyrodniczych. Czy jednak główna cecha rozumienia, a więc jej ugruntowanie w przeżywającym i wartościującym człowieku nie sprawi, że wszelkie poznanie za jej pośrednictwem obciążone będzie wartościowaniem? Pytanie to zajmuje Webera w dalszej części tekstu, przy czym od początku stara się on unikać utożsamiania pojęć rozumienia i wartościowania. Jako przykład podaje filologię, w której niewątpliwie stosuje się metodę rozumienia, ale jednocześnie obiektywizuje się przedmiot badań, uwalniając tym samym pracę badawczą od wartościowań.

Większym problemem jest jednak możliwość, że wartościowanie nieuchronnie związane jest z rozumieniem za sprawą myślenia teleologicznego, co ograniczałoby wyjaśniająca siłę „rozumienia” albo kazałoby nam powrócić do odrzuconego wcześniej błędnego koła funkcjonalizmu. „Teleologia” jest jednak, według Webera, pojęciem niejednoznacznym (1988a: 86-88). Może mieć węższy zakres niż „rozumienie”, gdy rozumieć przez nią orientację na cel, wszak „rozumieć" można nie tylko działania zorientowane na cel, ale także na przykład czysto afektywne. Może mieć też zakres szerszy, jeśli rozumieć prze nią wszelkie interpretacje z punktu widzenia stanu docelowego (popularne także w biologii).

Z punktu widzenia podmiotu myślenie teleologiczne (choćby w kategoriach działania celowego) nie oznacza ignorowania przyczynowości, przeciwnie - każda sensowna próba realizacji celu wymaga wiedzy przyczynowej. W wypadku, gdy przez teleologię rozumie się z kolei „teleologiczne tworzenie pojęć" w odniesieniu do wartości, to tego rodzaju teleologia nie zastępuje w żaden sposób przyczynowości, lecz raczej, jak już wspominałem, wyprzedza obiektywizację. Teleologii można się też dopatrywać w normach społecznych, zwłaszcza prawnych. Chociaż, według Webera, tworzenie pojęć przez dogmatykę prawniczą ma w istocie charakter teleologiczny, 
to historia i socjologia prawa interesują się raczej faktycznym posłuchem wobec norm i ich historycznymi zmianami w szerszym kontekście społecznym, nie ujmują więc procesów prawnych teleologicznie. Ostatnim wreszcie źródłem myślenia teleologicznego może być rozumienie woli takiej, jaka jest bezpośrednio dana w doświadczeniu. W tym wypadku teleologia także nie pozostawałaby w sprzeczności z przyczynowością. Weber uważa nawet, wbrew Münsterbergowi, że wola może być obiektywizowana, o ile obiektywizacja uwzględnia pojmowalność woli, jej przynależność do „Ja", a założenia te sa prawdami ponadindywidualnymi, czyli powszechnie zrozumiałymi i akceptowalnymi. Rozumienie posługuje się więc nieco innymi środkami niż jednoznaczne formuly wiedzy obiektywnej. Interpretacja wymaga pojęć o wysokim stopniu określoności, a nie ogólności. Wbrew temu, co jeszcze dziś twierdzi choćby Jeffrey Alexander (1995: 123), postęp wiedzy socjologicznej nie polega jedynie na zwiększaniu ogólności twierdzeń, to bowiem, zgodnie z koncepcją Webera, musiałoby niechybnie prowadzić do pozbawienia jej treści. Postęp ten wymaga raczej zwiększania adekwatności pojęć opisujących rzeczywistość w sposób wydobywający charakterystyczne cechy zjawisk. „Rozumienie” ma zatem podwójne oblicze. Z jednej strony, pobudza do zajęcia stanowiska wobec danego obiektu przez wzbudzenie określonych uczuć wobec niego, a w konsekwencji do wartościowania, z drugiej zaś, umożliwia wydanie sądu potwierdzającego istnienie realnego związku między faktami jako związku „zrozumiałego”, który może stanowić podstawę podejmowania racjonalnych decyzji.

Oddzielenie drugiego $\mathrm{z}$ wymienionych aspektów rozumienia umożliwia „przyczynowe poznawanie” rzeczywistości. Nie oznacza to, że aspekt pierwszy nie ma niezależnej wartości poznawczej - na przykład przy interpretacji dzieła sztuki, co z kolei pozwala na zrozumienie intencji twórcy, specyfiki dzieła itd. Pomieszanie obu aspektów, nierozłącznie współwystępujących w samym akcie rozumienia, może prowadzić do wydawania sądów wartościujących w imieniu nauki, a więc z roszczeniem ich prawdziwości, naukowej sprawdzalności. Istotą Weberowskiej zasady wolności od sądów wartościujących jest sprzeciw wobec takiej praktyki. Sądów wartościujących nie da się bowiem poddać sprawdzianowi, posługując się kryterium celu poznawczego, lecz ,innych celów czy wartości uczuciowych rzeczywistości życia" (Weber 1988a: 90). Pierwszym argumentem Webera na rzecz omawianej tu zasady jest więc argument z logicznej niewspółmierności (Maßstab) celu sądów poznawczych i wartościujących. Choć można uzasadniać zarówno sądy poznawcze (np. „ustrój średniowiecznych miast włoskich przyczynił się do rozwoju kapitalizmu w Europie”), jak i wartościujące (np. „polityka 
wschodnia Niemiec powinna opierać się na przyjaznych stosunkach z Polska"), to sądy wartościujące nie wynikaja z poznawczych, wszak implikują też wyobrażenie celu, który nie ma charakteru poznawczego i nie podlega procedurom sprawdzenia naukowego. Do owych celów należy, jak już wspomniałem, między innymi sam autoteliczny cel poznawczy, którego nie można wywieść z treści poznania. Wniosek ten wynika z argumentu, do którego doprowadziła Webera polemika z Roscherem, argumentu $\mathrm{z}$ nieskończonego regresu funkcjonalnego dopasowania. Jak pamiętamy, ostateczny układ odniesienia musi pozostać przedmiotem wiary. Wniosek ten wzmocniła jeszcze dyskusja z poglądami Wundta, gdy okazało się, że nie ma nawet potrzeby odwoływania się do przyczyn celowych, by wyjaśniać zjawiska psychiczne i społeczne.

Logiczna niewspółmierność i fakt, że cel wartościowania nie jest zgodny z celem poznawczym, ponieważ sam wymaga podania innej racji wartościującej, nie oznacza jeszcze, że sądy poznawcze formułowane dzięki zasadzie rozumienia nie zawierają implicite sądów wartościujących. Koncepcja rozumienia w gruncie rzeczy pociaga za sobą takie stanowisko ze względu na podwójną naturę aktu rozumienia. „Prawdą jest, że przy «interpretującej» syntezie indywidualnego procesu historycznego lub «Osobowości» historycznej używamy pojęć wartościujących, których «sens» ciągle "przeżywamy», działając i odczuwając jako podmioty zajmujące stanowisko" (Weber 1988a: 91). Skoro obiekt badań nauk o kulturze ukształtowany jest przez cel poznawczy, który sam nie podlega uzasadnieniu przez sądy poznawcze, to już sam wybór i określenie obiektu odnoszą się do wartości (Wertbęiehung), które świadomie lub nieświadomie reprezentuje badacz. W tym sensie na pytanie, czy wartościowanie jest nieuniknionym elementem rozumienia, należałoby odpowiedzieć twierdząco.

Weber przeformułowuje jednak pytanie o wartościujący charakter rozumienia, odwołując się do ukierunkowującego charakteru celu poznawczego/wartościującego. Zamiast skonstatować fatalną niemożność pozbycia się wartościowań, Weber zastanawia się, czy przeszkadzają one w realizacji celu poznawczego. Otóż według niemieckiego socjologa wartościowania wręcz umożliwiają realizację celu poznawczego. Obiekt jest wszak obiektem badawczym jedynie dzięki odniesieniu do wartości. Dzięki niemu również możliwy jest sam proces badawczy, selekcja grup przyczyn, które wchodza w grę przy formułowaniu praw nauki, i interpretacja tych praw. Jako funkcja badawcza odniesienie do wartości przekształca wartościowanie w operację teoretyczną, a aktywny stosunek 
przeżywającego podmiotu do otaczającego go świata w „rozumienie” jako kontrolowaną metodę interpretacji.

Dwoista natura „rozumienia” i konieczność wyraźnego oddzielenia obu aspektów przez określenie funkcji tej metody jest problemem, do którego odnosi się teoria rozumienia. Weber stara się stworzyć w swym tekście zarys takiej teorii, odwołując się do autorów, którzy podejmowali przed nim podobne próby, w szczególności do socjologa Georga Simmela, psychologa Theodora Lippsa oraz historyka Friedricha Gottla. Na tym etapie analizy Weber zmierza do wskazania specyficznych mechanizmów psychicznych umożliwiających „rozumienie” oraz konsekwencji, jakie niesie ono dla poznania w ogóle. Na początek rozprawia się z próbami zakreślenia ograniczonej grupy obiektów, do jakich mogłoby się odnosić „rozumienie”. Tak więc, wbrew Heinrichowi Rickertowi, twierdzi, że „uczucia wartościujące w żadnym razie nie muszą się wiązać jedynie z «wyjątkowością» [Einzigartigkeit], lecz także z powtarzaniem się" (Weber 1988a: 92 p. 1). Następnie polemizuje z Simmelowskim przeciwstawieniem „rozumienia” sensu wyrażenia oraz „interpretacji” motywów działania, zgodnie z którym „rozumienie” dotyczyć może tylko poznania treści dających się przedstawić w formie logicznej. Weber wskazuje tymczasem, że rozumienie mowy dochodzi do skutku także podczas słuchania i wykonywania rozkazów czy apeli do sumienia, uczuć i wartości, a więc gdy nie chodzi o interpretację teoretyczna, lecz wywoływanie praktycznego odczuwania i działania (performatywny aspekt mowy). Rozumienie może więc dotyczyć sensu wyrażonego w jakiejkolwiek formie. Koncepcja Simmela była jednak o tyle ważna dla Webera, że pozwoliła mu wprowadzić rozróżnienie między bezpośrednim ,aktualnym rozumieniem” pytania, twierdzenia czy apelu a „rozumieniem teoretycznym”, któremu Weber nadaje status metody badawczej. To ostatnie podobne jest pod względem mechanizmu psychicznego do rozumienia wywołanego przez początkowy brak zrozumienia sensu wypowiedzi. Niejasność przekazu powoduje konieczność postawienia sobie pytania o motyw nadawcy, cele, jakie sobie stawiał. Tylko wtedy dochodzi do głosu konieczność ujęcia jego działania w schemat przyczynowy. Dzięki wyjaśnieniu przyczynowemu możliwa staje się bowiem odpowiedź na noetyczne pytanie o sens. Interpretacja teoretyczna może oczywiście, jak wspomniałem, służyć celowi praktycznemu albo teoretycznemu. Jedynie w tym ostatnim wypadku, a więc gdy dokonywana jest na potrzeby „rozumienia”, będzie zgodna z intencja metodologiczną Webera. Natomiast całkowite wyłączenie własnej zdolności przeżywania, specyficznie ludzkiego punktu widzenia, byłoby nie tylko niemożliwe, ale zgubne dla wiedzy historycznej. Trafnie 
zilustrował to Simmel: „Gdy Ranke mówi, że chce wyłączyć swa jaźń, aby widzieć rzeczy takimi, jakie naprawdę były, to spełnienie się tego życzenia przekreśliłoby zamierzony skutek" (1892|1989: 321).

„Rozumienie”, o którym tu mowa, wymaga umiejętności dystansowania się wobec rzeczywistości, a także własnego sposobu odnoszenia się do niej, po to, by ów specyficznie ludzki sposób odnoszenia się zastosować instrumentalnie w celach badawczych. Ów dystans sprawia, że stosunek historyka do swego przedmiotu staje się podobny do stosunku, jaki przyrodnik ma do natury. Zdaniem cytowanego przez Webera historyka Friedricha Gottla, „poznanie historyczne” pozwala uzyskać dostęp do właściwego przedmiotu historii, którym jest sens działań, podczas gdy ujawnianie ich kolejnych, zewnętrznych uwarunkowań pozwala jedynie dostrzec szersze powiązania i kontekst „przeżycia” wydobytego ze swych zewnętrznych powiązań przez początkowy akt rozumienia (Weber 1988a: 98-99). W ujęciu Gottla kluczowe dla nauk przyrodniczych wyjaśnienia przyczynowe odgrywaja jedynie drugorzędną rolę, w naukach historycznych nie dając żadnego pojęcia o rzeczywistości duchowej. Weberowskie pojęcie „rozumienia” różni się od Gottlowskiego już w tym miejscu, wszak Weber podważa tezę, iż interpretacja musi pojawić się zawsze na początku badań historycznych, i twierdzi, że w niektórych wypadkach jest wręcz w ogóle zbędna. Poza tym Weber wyraźnie odróżnia logiczną wartość sądów uzyskanych dzięki zastosowaniu metody rozumienia od sposobu, w jaki do rozumienia dochodzi w procesie wyjaśniania. Materiał badawczy nauk o kulturze nie „zawiera” niczego, co ze swej natury byłoby nie tylko odmienne od materiału nauk przyrodniczych, ale też przez swą odmienność dostępne tylko „przeżyciu”. Przydatność „rozumienia” wynika raczej z natury poznania dochodzącego do skutku przez odniesienie do wartości. Przenoszenie owego odniesienia na przedmiot poznania wydaje się już Weberowi nieuprawnione. Wskazują na to zresztą daleko idące zbieżności między naukami przyrodniczymi a naukami o kulturze - w obu przy formułowaniu hipotez (a więc w tym, co Kant określał jako kontekst odkrycia) fantazja odgrywa równie dużą rolę, w obu też testowanie hipotez podlega podobnemu rygoryzmowi logicznemu (Weber 1988a: 98).

Przykładem poglądu o szczególnym pokrewieństwie rozumienia z jego przedmiotem jest przekonanie, że historia odsłania badaczowi zasady rozwojowe będące odzwierciedleniem reguł myślenia, jak również teza, że rozumieniu podlega jedynie myślenie racjonalne. Weber dowodzi tymczasem, że zrozumiałość działania wcale nie musi oznaczać jego racjonalności. Oczywiście, interpretując czyjeś postępowanie, zaczynamy od przypisania podmiotowi jakiegoś racjonalnego motywu (i poznania jego 
hierarchii wartości), ale to nie oznacza, że nie jesteśmy w stanie zrozumieć działania nieracjonalnego. Jest ono trudniejsze do zrozumienia, ale nie sprawia, że rozumienie polega tylko na znajomości zasad poprawnego myślenia. Według Webera racjonalność działania jest raczej tylko hipoteza, która może zostać przez „rozumienie” potwierdzona w większym lub mniejszm stopniu. Stąd też teorii Webera nie należy interpretować jako teorii działania racjonalnego, a co najwyżej, jak uważa Wolfgang Schluchter (1979: 192), jako teoretyczną skalę racjonalności działania. Jeśli jednak rozumienie nie jest ograniczone do uniwersalnych reguł racjonalnego myślenia, to powstaje pytanie, jak możliwe jest w ogóle uzyskanie dostępu do nieracjonalnych, idiosynkratycznych wyobrażeń innej osoby. Jak pisze Simmel, ,skoro jako zadanie historii określiliśmy wyżej nie tylko poznawanie tego, co poznane, lecz także tego, co pożądane i odczuwane, to jego realizacja możliwa jest przez to, że za sprawa jakiegoś psychicznego przestawienia to, co pożądane, będzie współpożądane, a to, co odczuwane - współodczuwane" (Simmel 1892|1989: 318). Na czym innym może polegać „rozumienie”? Pytanie to ponownie stawia Webera przed tezą Kniesa o irracjonalności jednostki, choć tym razem irracjonalność jest już co najwyżej odchyleniem od dominującego standardu działania racjonalnego, a co za tym idzie, zrozumiałego.

W odpowiedzi na postawione pytanie w sukurs Weberowi przychodzi ponownie Simmel, który uważał, że poznanie Innego jest z konieczności podobne do poznania samego siebie i może być wyjaśnione za pomoca tezy o biologicznych prawidłowościach ludzkiego przeżywania, które wynikaja z odziedziczonych po wspólnych przodkach zdolności poznawczych, a nawet treści (archetypów). Weber nie zadowala się jednak tą nowoczesną wersją Platońskiej anamnezy i formułuje problem genezy konkretnego poznania, które jako „rozumienie” dotyczyć ma przecież nie tyle powtarzających się wyobrażeń i doświadczeń, lecz tego, co jakościowo szczególne i nowe w każdym konkretnym przeżyciu (Weber 1988a: 10-101 p. 1). W tym sensie całkiem nowych (własnych) przeżyć wymaga nie tylko rekonstrukcja przeżycia (Nacherleben) innej osoby, ale i takiego, którego doświadczyło się samemu. Jeśli rozumienie samego siebie jest możliwe mimo jakościowej odmienności każdego kolejnego przeżycia, to sama jakościowa odmienność nie powinna być przeszkodą w rozumieniu Innego. Webera zainspirowało zwłaszcza spostrzeżenie Simmela, że lepiej „rozumiane” (w sensie Webera) są właśnie osobowości „o wyraźnych rysach” i wysoce ,indywidualne” (Weber 1988a: 101 p. 2). „Rozumiemy” bowiem to, czemu przypisujemy wartość, i to, co jako takie nas interesuje. Wartość przypisujemy z kolei zjawiskom wyjątkowym, a im bliższe 
są one przeciętności, tym mniejsze okazujemy im zainteresowanie. Innymi słowy, nowe zjawiska budzą uwage i pozwalaja dostrzegać nowe związki między obiektami, a także formować nowe ,jedności” poznawcze: „W ogólności pod tą jednością rozumie się to, że działania i wyobrażenia człowieka maja cechy pozwalające nam pojmować je jako wytwory numerycznie prostej i niezmiennej istoty duchowej. Ponieważ ta stanowi jednak zwykłą niewiadomą «x», o której już nic więcej nie możemy powiedzieć, jedność istoty oznacza, że możemy wzajemnie sprowadzić do siebie ludzkie wyobrażenia i wyjaśnić jedno drugim. To wymaga wszakże pewnych zasad, których panowanie unaocznia nam właśnie jedność osobowości, której nie możemy bezpośrednio obserwować" (Simmel 1892|1989: 335). Opisana tu przez Simmela geneza odniesienia do wartości nie rozwiąuje wprawdzie sama w sobie problemu poznania Innego, ale każe zakwestionować tezę o „pewności” poznania samego siebie, która leży u podstaw przeciwstawienia własnych przeżyć i rekonstrukcji przeżyć Innego. Ta „pewność” odnosić się może co najwyżej do bezpośredniego przeżywania w danej chwili, ale takie przeżywanie nie jest przedmiotem sądów poznawczych, podlegającym wyjaśnianiu naukowemu. Przedmiotem takim stanie się jedynie wtedy, gdy przyjmie postać pojęciową w ramach logicznej struktury doświadczenia, wspólnej dla wszystkich ludzi. Dopiero poddanie się prawom logiki nadaje przeżyciom obiektywność epistemiczną. Obiektywność ontologiczna, a więc wynikająca z osobistego przeżycia, dotyczy zresztą wyłącznie samego faktu przeżywania, a niekoniecznie jego treści. Ta wymaga już bowiem wspomnianego odniesienia do wartości. „...nasze własne, współokreślające wartościowanie i działanie «nastroje» - w znaczeniu wulgarnej psychologii - nie są dla nas w swym sensie [...] w żaden bezpośredni sposób «interpretowalne»" (Weber 1988a: 104). Interpretacja wymaga odwołania się na zasadzie analogii do celowo wybranych przeżyć innych osób. To dzięki nim możemy izolować, analizować i kontrolować własne przeżycia, w tym rekonstrukcje przeżyć innych. Ta intersubiektywna praca nie byłaby zaś możliwa bez uprzedniego odniesienia do wartości.

Dotychczasowa argumentacja Webera rozpoczęła się od stwierdzenia dualizmu w nauce, którego pozornie nie przezwyciężyła. Od przeciwstawienia prawa i rzeczywistości, przez ich utożsamienie u Roschera, Weber doszedł do metodologicznego rozróżnienia między wyjaśnianiem przyczynowym i ,rozumieniem”. Chociaż to ostatnie udało mu się uznać za istotny moment wyjaśnienia przyczynowego, to szybko okazało się, że zawarte w ,rozumieniu” odniesienie do wartości umożliwia wyjaśnienie przyczynowe, kierując procesem poznania. Obserwacja ta zmusiła Webera 
do dokładniejszego określenia zasad rozumienia jako metody badawczej po to, by ograniczyć „dowolność” wartościowania i zachować suwerenność poznania naukowego. W ramach tych poszukiwań właściwej formuły „rozumienia” Weberowi udało się, po pierwsze, sformułować hipotezę racjonalności ludzkich działań, po drugie, wyjaśnić powstanie odniesienia do wartości w samym procesie poznawczym, a konkretnie w odchyleniach od stwierdzanych prawidłowości i wreszcie, po trzecie, zidentyfikować główną intelektualną funkcję rozumienia w akcie intersubiektywnej interpretacji. Wszystkie te trzy istotne spostrzeżenia pozwoliły na podważenie tezy Kniesa o irracjonalności człowieka, podobnie jak wcześniej udało się odrzucić tezę Roschera o ostatecznej irracjonalności świata. Co jednak sprawiło, że Weber zajął się w ogóle rozpatrywaniem zagadnienia rzekomej irracjonalności człowieka? Motyw ten nietrudno znaleźć w strukturze analizowanego dotąd tekstu. Było nim dostrzeżenie (widoczne także w Etyce protestanckiej) napięcia między porządkiem przyczynowym świata a sprzeciwem człowieka wobec tego porządku w imię wartości - napięcia, które Albert Camus określiłby jako „metafizyczny bunt”, tyle tylko że Weber zaobserwowal go nie u ateistów, lecz u osamotnionej jednostki stającej po stronie Boga. Czy sprzeciw ten jest irracjonalny? Dotychczasowe rozważania pozwoliły mocno zawężyć obszar irracjonalności do tej części życia psychicznego, które nie da się pojmować jako racjonalne realizowanie celów i które wyznacza same te cele. Obszar ten został w dużej mierze skonceptualizowany jako odniesienie do wartości, ale możliwości zrozumienia jego sensu nie zwiększyły się. Stąd też Weber bada ostatnią możliwość, a mianowicie, czy intersubiektywistyczna koncepcja poznania dostarcza specyficznych nowych możliwości „rozumienia” nie tylko działania, ale owego specyficznie ludzkiego składnika rzeczywistości - bytu, który, choć pewny, wymyka się właśnie tej metodzie, która w nim jest ugruntowana (i w którym, jak się okazało, ugruntowane jest wszelkie poznanie).

Do bliższego rozpatrzenia poznania ,intersubiektywnego" zainspirował Webera psycholog Theodor Lipps i jego koncepcja „wczuwania się” (Einfüblung). Jest ona od początku mniej intelektualistyczna niż koncepcja rozumienia racjonalnego i oferowała Weberowi możliwość znalezienia specyficznego elementu międzyludzkiej interakcji, który mógłby być uznany za podstawę racjonalności (Weber 1988a: 106-110). Dla Lippsa ,interpretacja" to także przyswajanie wartości estetycznych i wyrażeń afektywnych w ogólności. Polega na wewnętrznym odtwarzaniu (Nachabmung) działania jako własnego. Nie chodzi przy tym o refleksję nad cudzym postępowaniem jako takim, lecz wewnętrzne przeżycie, którego treścią jest postawienie się na miejscu Innego, wewnętrzne wyobrażenie, że przeżywa się to, co 
Inny, któremu to wyobrażeniu towarzyszy wyłączenie świadomości, że nie jest się Innym. Identyfikacja z Innym (człowiekiem lub innym obiektem) stanowi więc przesłankę wczucia się. Doświadczenie estetyczne wyczerpuje się w takim identyfikacyjnym przeżywaniu, doświadczenie intelektualne wymaga zaś kolejnej fazy - przywołania do świadomości pozostającego dotąd w tle sądu o nietożsamości podmiotu przeżywającego i Innego. „Ja" rozpada się wtedy na wyobrażone i realne, dzięki czemu rozpocząć może obiektywizację rzeczywistości.

Samo „wczucie się" wymaga wszakże spełnienia pewnych warunków, a mianowicie uprzedniego doświadczenia przyczynowości w świecie, toteż dziecko nie potrafi, według Lippsa, utożsamić się na przykład z obserwowanym linoskoczkiem (Weber 1988a: 107). Pierwotne doświadczenie przyczynowości, o jakim tu mowa, nie ma nic wspólnego z obiektywna przyczynowością nomologiczna, lecz przeżywaniem sił przyczynowych, dążeń, oddziaływania w świecie, w tym zwłaszcza oddziaływania przyczynowego przez podmiot. Dlatego też człowiek jest zdolny do wczuwania się w obiekty przyrody, wyobrażając sobie ich wzajemne oddziaływania, jakby chodziło o jego własne siły. Przeżywana „natura” składa się z „rzeczy” ukonstytuowanych przez wyobrażenia oddziaływań doświadczanych w samym sobie. „Rzeczowość” własnego „Ja” jest jednak, według Lippsa, jedyna prawdziwa, a obiekty świata z niej właśnie czerpią swą wyobrażoną realność. Niemieckiego psychologa dzielił już tylko krok od uznania samego „Ja" za produkt wymiany gestów w fazie, gdy dziecięce „Ja" nie identyfikuje jeszcze swego ciała w opozycji do otaczających je rzeczy. Ten wniosek, który stał się później udziałem George’a Herberta Meada, oznaczał już intersubiektywną konstytucję świata. Podobnie jak Lipps Mead musiał zacząć od opracowania skutków identyfikacji (przejęcia roli) dla teorii poznania.

Koncepcja Lippsa i jej podobne nie mają z pozoru większej wartości dla metodologicznych rozważań Webera, gdyż odtwarzanie przeżyć Innego nie przynosi żadnej wiedzy o jego faktycznych przeżyciach ani nawet o własnych, skoro samemu nie jest się w sytuacji tej osoby. Rozważania Lippsa dowodzą jednak, że podmiot ma zdolność do wypierania świadomości samego siebie w momencie stawiania się w miejscu Innego (Weber, w odróżnieniu od Lippsa, nie nazywa tego rozdwojeniem - Spaltung). Bardziej interesujące konsekwencje ma jednak wniosek o wyłącznej realności „Ja” jako rzeczy. Powstaje pytanie, czym są rzeczy i czy istnieja pojęcia rzeczowe? Według cytowanego przez Webera Benedetta Crocego pojęcia moga się odnosić jedynie do związków między „oglądami” (Anschaunngen), a te ostatnie same miałyby już być rzeczami. 
Historia jako pamięć oglądów miałaby w związku z tym status sztuki a nie nauki. Weber odróżnia tymczasem pojęcie „oglądu” w znaczeniu naukowej zasadności i oczywistości od „oglądu” w znaczeniu odczucia jedności treści świadomościowych. Lipps i Croce mieli na myśli to ostatnie, podczas gdy badacze piszący o „rzeczach” dokonują selekcji elementów spośród bardzo różnorodnego materiału i czynią to z określonego punktu widzenia, który decyduje o tym, co stanowi ,istotę rzeczy”. Tak rozumiana „rzecz” jako przedmiot badawczy pozostaje więc z tym, co bezpośrednio dane, jedynie w związku funkcjonalnym, stanowi produkt myślowy. W związku z tym historia i nauki o kulturze operuja jedynie pojęciami względnymi (takimi jak wspomniana wcześniej „osobowość”). Nie jest możliwe naukowe „odzwierciedlenie” rzeczywistości, ponieważ każdy sąd egzystencjalny zakłada już operacje logiczne wykraczające poza „ogląd” w znaczeniu Lippsa.

Polemika Webera z Lippsem prowadzi do wniosku, że wprawdzie moment identyfikacji i umiejętność „wyłączenia” "Ja” są niezbędnymi momentami „rozumienia”, ale konstytucja rzeczy jest dziełem myśli, a nie samej tylko identyfikacji. Rozumienie nie byłoby w tym kontekście samym „wczuciem się”, lecz myślowym przekształceniem „wczucia” w doświadczenie, które zakłada generalizację i względną określoność pojęć (selekcję elementów przyczynowych). Te operacje wymagaja z kolei stosowania reguł doświadczenia, na przykład reguł sprawczości, pozwalających zinterpretować sekwencje działań w polityce, gospodarce, prawie itd. Reguly takie są stosowane powszechnie w życiu codziennym, choć nie zdajemy sobie z tego zwykle sprawy. Stanowią wiedzę, która pozostaje w tle zwyczajnych czynności i czasem wywołuje uśmiech, gdy w celach humorystycznych umieszczana jest w sentencjach i mądrościach życiowych. Logiczna struktura poznania, a więc generalizacje i powiązania specyficznych pojęć stosowanych ze względu na cel poznawczy, staje się widoczna dopiero w momencie problematyzacji ważności empirycznej. Okazuje się wtedy, że sposób poznania (np. wczucie się, identyfikacja czy wzajemna identyfikacja) nie ma znaczenia dla wykazania jego logicznego sensu i prawdziwości. A zatem Weber oddala nadzieję na to, że w „postawieniu się na miejscu Innego" czy też w ,intersubiektywności” kryje się możliwość uzasadnienia wiedzy o rzeczywistości ludzkiej. Mimo to jego dociekania nie okazały się bezowocne. Spodziewał się wprawdzie, że mechanizm „wczucia się” pozwoli mu dotrzeć do punktu odniesienia wszelkiego poznania, okazało się jednak, że próba opisania czy wyjaśnienia tego mechanizmu wymaga odniesienia do reguł doświadczenia i generalizacji, które z kolei wymagają adekwatnych pojęć, a te mogą być tylko 
względnie określone, gdyż muszą być odniesione do wartości. Jeśli zatem cokolwiek pozostaje jeszcze poza zasięgiem wyjaśnienia przez rozumienie, są to właśnie wartości ostateczne. Okazało się również, że rozumiejąca interpretacja dostarcza zupełnie innej pewności niż zjawiska przyrodnicze czy prawa matematyki. Nie jest to pewność w znaczeniu słuszności logicznej, „obowiązywalności” prawa naukowego, a jedynie ewentualność. Gdy więc chodzi o sformułowanie wyjaśnienia, może służyć do sformułowania hipotezy, a jeśli zachodzi potrzeba stworzenia pojęć ogólnych, będzie podstawą do skonstruowania „typu idealnego".

W omawianym tekście uwaga Webera stopniowo coraz bardziej skupia się na wartościach, które najpierw okazują się potrzebne w procesie rozumienia i wyjaśniania naukowego, a następnie jawią się jako ostateczne założenia badawcze, nieredukowalne do bezpośrednich przeżyć. Weber rozpoczyna rozważania nad wartościami od analizy „uczuć wartościujących”, a więc jakości doświadczenia, które pozwalają rozumiejąco dookreślać pojęcia w celu unaocznienia natury zjawisk kulturowych. Historyk może na przykład prowokować swych czytelników do pewnych przeżyć, które pozwalają lepiej zrozumieć koloryt epoki i dominujące w niej postawy. Tak wywołane uczucia pozostają wszakże własnymi uczuciami historyka i jego czytelników, nie są uczuciami ludzi omawianych czasów, nie mają wagi kryterium rozróżnienia przyczyn ,ważnych” i ,nieważnych”. Mimo że interpretacja, do jakiej prowadza, jest jedynie subiektywna i nie pozwala na empiryczne poznanie prawdziwych związków historycznych, to otwiera możliwość „interpretacji odniesionej do wartości”. Weber nazywa tak interpretację polegająca na przypisaniu ludziom, dziełom i wydarzeniom z przeszłości własnych wartości badacza. Nawet jeśli lektura książki historycznej, poezja, malarstwo czy osobiste relacje pochodzace $z$ danej epoki nie pozwalają nam myślowo zrekonstruować ówczesnych wartości, to zwiększają spektrum naszych możliwych odniesień do wartości. Pozwalają nam poznać wartości, których dotąd nie znaliśmy, ale także zdystansować się wobec tych, które stanowiły nasz dotychczasowy układ odniesienia, a nawet podjąc ich naukową analizę. Początkowe „wczucie się” w materiał historyczny, będące całkowitą utratą dystansu, zwykłym wartościowaniem, przekształca się paradoksalnie w dystans i samokontrolę badawcza. Nieokreśloność „wczucia się” zamienia się w określoność pojęć, podobnie jak wcześniej nieokreśloność łańcuchów przyczynowych zamieniała się w wyraźne związki między indywiduami historycznymi. Odniesienie do wartości pełni zatem funkcję naukowa, nie tylko umożliwiając formułowanie praw przyczynowych, ale i dystans rozumienia.

Kontrast między nieokreśloną i subiektywna „treścią uczucia” a odniesieniem do wartości nabiera u Webera coraz wyraźniejszego kształtu. 
Wyłania się wraz z kolejnymi dookreśleniami samych „wartości”, a więc właściwego przedmiotu Weberowskich dociekań. Autor Etyki protestanckiej pisze wszak, że „w przeciwieństwie do zwykłej «treści uczucia» jako «wartość» określamy właśnie to i tylko to, co może być przedmiotem ustosunkowania się [Inhalt einer Stellungnahme]; wyraźnie świadomego pozytywnego i negatywnego «sądu»” (1988a: 123), a dalej: „...dla celów naszych rozważań musimy stwierdzić, że określoność treści sądu jest tym, co wydobywa ze sfery «uczucia» obiekt, do którego [sądy wartościujące] się odnoszą " (1988a: 123). Wartości różni od uczuć także to, że są komunikowalne i mogą być akceptowane przez Innych, podczas gdy uczucia pozostaną subiektywne: „Powiedzenie o kimś, że podziela sąd etyczny lub estetyczny o jakimś fakcie, nie miałoby żadnego sensu, gdyby - mimo wszelkiego udziału niekomunikowalnych czynników uczuciowych przypisywana temu komuś treść sądu nie mogła być tak samo «rozumiana» w punktach, o które chodzi" (1988a: 123). Weber nie ma więc na myśli intersubiektywności wartości - bo przecież w świetle omawianych już fragmentów tekstu ani fakt identyfikacji z Innym, ani nic innego nie wskazuje na to, by ostateczne wartości były przedmiotem uzgodnień lecz chodzi mu o roszczenie obiektywności wysuwane przez wszystkich, którzy za wartościami się opowiadają.

Odróżnienie wartości od uczuć jest niezwykle ważne nie tylko z tego względu, że definiuje wartości, ale także dlatego, że zawiera cenną wskazówkę co do rozumienia zasady wolności od sądów wartościujących, do której omówienia przejdę w dalszej części tekstu. Otóż w Die Objektivität sozialwissenschaftlicher und sozialpolitischer Erkenntnis, omawiając istotę postulowanej przez siebie zasady, Weber pisze, że oprócz obowiązku ujawniania swych wartości, składa się na nią obowiązek oddzielania argumentów skierowanych do rozumu od tych skierowanych do „uczuć” (1988b: 155; 157). Widoczna tu sprzeczność może na pierwszy rzut oka sugerować, że Weber wywodził wartości z „przeżycia”, a więc tego, co dane jest we „wczuciu się”. Akt zdystansowania się wobec własnego „uczucia” przetwarzałby je we wspomniane roszczenie do obiektywności własnego stanowiska wyrażalnego w postaci sądu i zrozumiałego dla innych. Apel o nieodwoływanie się przez uczonych do uczuć wiązałby się zaś z faktem, że to, co dane jest we „wczuciu się”, nie podlega dalszemu uzasadnieniu, a jako takie nie jest przedmiotem krytyki naukowej. Interpretacja ta wydaje mi się jednak przedwczesna. Warto raz jeszcze przypomnieć, że wyjściowy problem postawiony przez Webera w polemice z Kniesem dotyczył w gruncie rzeczy ludzkiej wolności wyboru wartości. Tymczasem odrzucając argumenty Wundta, Münsterberga, Lippsa i Gottla, Weber dowodził 
zarazem, że teleologicznie pojęte działanie, kreatywność, „osobowość”, subiektywny punkt widzenia czy wreszcie „wczucie się” i myślowa konstytucja rzeczy nie unieważniają uniwersalizmu i koniecznego charakteru praw przyczynowych. Nie unieważnia go nawet racjonalność ludzka, która z jednej strony korzysta z praw przyczynowych, a z drugiej, sama jest przejawem ich działania. W gruncie rzeczy nic nie stałoby na przeszkodzie, by przyjąć tezę o determinacji samych wartości, które zakłada schemat celu-środków. W ten sposób z wolności człowieka nic by nie pozostało, byłaby ona tylko innym określeniem świadomości, że działa się racjonalnie lub że popełnia się błąd będący odchyleniem od ideału racjonalności. Jak paradoksalny byłby taki wniosek, wskazuje zdanie samego Webera pod koniec tekstu na temat Roschera i Kniesa, mówiące, że im człowiek jest bardziej wolny, tym bardziej jest ...zdeterminowany: „Im bardziej wolna jest «decyzja» działającego, a więc im bardziej oparta na «własnych», niezaburzonych «zewnętrznym» przymusem lub nieodpartymi «afektami» kalkulacjach, tym pełniej może się udać jej racjonalna analiza i ewentualnie wkomponowanie do schematu działania racjonalnego, tym większa rola, jaką (tak po stronie działającego, jak i analizującego badacza) odgrywa wiedza nomologiczna, a co za tym idzie, tym bardziej zdeterminowany jest działający ze względu na «środki»" (Weber 1988a: 132; podkr. M.K.).

Im głębiej Weber wnika w naturę poznania naukowego, tym bardziej dostrzega, że jest ono na wszystkich etapach odniesione do wartości. Stanowią one, podobnie jak prawa matematyki, ostateczne założenia poznania, choć w odróżnieniu od praw matematyki są historycznie zmienne. Próba przyczynowego wyjaśnienia wartości, która mogłaby anulować potrzebę ich uzasadnienia, prowadziłaby jednak do groźby błędnego koła konstruktywizmu, wszak nauka wyjaśniałaby wartości, które od początku określaja jej prawa. Tym samym wagi nabiera pytanie: Jak wiele nauka może powiedzieć o wartościach? Jak można się spodziewać, od niego właśnie rozpoczyna się kolejny kluczowy tekst Webera dotyczący naszego tematu. Jedynie na marginesie warto dodać, że zasada wolności od sądów wartościujących służyć może przerwaniu wspomnianego błędnego koła, a więc moment, w którym zostaje sformułowana, dobrze wpisuje się w wewnętrzną strukturę argumentacji Webera.

\section{/// III}

Istotna różnica między omawianymi dotąd artykułami Webera a tekstem Die Objektivität sozialwissenschaftlicher und sozialpolitischer Erkenntnis (1988b) polega na tym, że ten ostatni jest manifestem programowym. Wątki krytyczne 
pojawiaja się w nim rzadko i mniej wprost, wyraźniej natomiast dochodza do głosu poglądy samego Webera, choć osobisty ton osłabiany jest przez fakt, że cały artykuł stanowi program czasopisma naukowego i pisany jest w imieniu redakcji. Tematyka czasopisma nie ma być przy tym czysto naukowa, lecz ma obejmować również krytyczne komentowanie zagadnień gospodarczych i politycznych w sposób profesjonalny i pozbawiony politycznej zaciętości. Jest to najbardziej oczywisty powód, dla którego na pierwszy plan wybija się w tym tekście problem możliwości wartościowania (szczególnie politycznego) w ramach działalności naukowej. Ponieważ „Archiv für Sozialwissenschaften” pomyślany był przez swych założycieli jako pismo zarówno naukowo zajmujące się tematyką społeczna, jak i mające na celu „kształcenie do wydawania sądów o problemach praktycznych", to zalecenia, które Weber w nim formułuje, mogą być nieco mniej rygorystyczne niż zawarte w Wissenschaft als Beruf, a więc tekście skierowanym do społeczności akademickiej. Jak zobaczymy, nie jest to jednak różnica o zasadniczym znaczeniu, nawet jeśli wybija się w tekście. Ważniejsza jest struktura ogólnej argumentacji i miejsce, jakie zajmuje w niej problem postawiony przez Webera już na pierwszych stronach obecnie omawianego artykułu. Skoro pismo zakładało sobie cele praktyczne, ale zarazem w intencji wydawców miało być naukowe, czyli posługiwać się jedynie środkami w postaci wcześniej omawianych przez nas metod, to pojawia się pytanie, czy można wyprowadzać zalecenie praktyczne z tez naukowych. Z cała pewnością nauka może określić najbardziej efektywne środki realizacji danych z góry celów. Same cele jednak, a więc wartości zakorzenione w danej kulturze, wydają się, zgodnie z poprzednimi ustaleniami, wymykać naukowemu uzasadnieniu. Skoro tak, w jaki sposób można uzasadniać zalecenia praktyczne w piśmie naukowym? Problem ten dotyczy w istocie relacji między praktyką a teorią, tego, w jakiej mierze teoria sama może być praktyczna i może wydawać sądy na temat kultury, na która składają się między innymi ostateczne wartości. W poprzednio omawianym tekście pytanie to prowadziło do błędnego koła. Tym razem Weber postanawia więc przyjrzeć się bliżej temu, jak możliwe są nauki o kulturze. $\mathrm{Na}$ jego ogólne pytanie składają się szczegółowe kwestie dotyczące kryteriów oceny słuszności sądów praktycznych i możliwości obiektywnych (epistemicznie) prawd formułowanych przez nauki o kulturze.

Weber od początku zastrzega, że nie udzieli ostatecznej odpowiedzi na wymienione pytania: „Nie chcemy proponować rozwiązań, lecz wskazywać problemy” (1988b: 148). Można odczytywać to zdanie jako wstępną deklarację niewiedzy w odniesieniu do wartości. Weber rozpoczyna więc od wattpienia w możliwość poznania i uzasadnienia wartości, ale 
zarazem nie traci przekonania, że badania naukowe odgrywają niemała rolę $\mathrm{w}$ wartościowaniu i mogą także mieć znaczenie w krytyce wartości: „Krytyka nie boi się sądów wartościujących” (1988b: 149). Jak zauważa, wartościowanie jest historycznie ściśle związane z nauka, która mu służyła, zwłaszcza nauka jako technika. W takim rozumieniu działalność naukowa podobna była do medycznej i pomagała na przykład formułować zalecenia dla prawodawców czy ministrów finansów. Przekonanie o praktycznym walorze nauki wzmocnił niegdyś filozoficzny pogląd, że powinność jest zawsze tożsama z czymś, co istnieje lub nastąi. Wreszcie świadomość historyczna otworzyła drogę dla ewolucjonizmu etycznego i relatywizmu historycznego, które demaskując jałowość formalizmu norm etycznych, utożsamiły wszelkie normy społeczne $\mathrm{z}$ wartościami kulturowymi, te zaś podlegaja przecież poznaniu i wyjaśnieniu empirycznemu. Zarysowany przez Webera rozwój etyki znalazł podatny grunt w wizji nieświadomie przypisującej nauce funkcje praktyczne i to tym bardziej, im bardziej stawała się ona abstrakcyjna i w im większym stopniu ujmowała rzeczywistość w formuły ilościowe. W ten sposób nauka stawała się coraz mniej świadoma swych wartościujących założeń. Proces ten miał także prowadzić do wyniesienia ekonomii politycznej do rangi „nauki etycznej”, zdolnej do wydawania ocen wartościujących ze specyficznie „gospodarczego poglądu na świat” (1988b: 149). W oczach Webera ekonomia polityczna przestała być w rezultacie nauka, ponieważ „...zadaniem nauki doświadczalnej nigdy nie może być dostarczanie wiążących norm i wartości, z których można by wyprowadzać recepty praktyczne" (1988b: 149). Pogląd wyrażony tu przez Webera nie różni się od tego, który przedstawił w słynnej, nacjonalistycznie zabarwionej mowie freiburskiej z 1895 roku. Przedstawiając wtedy swój wartościujący punkt widzenia, oprócz tego, że opisywał ekonomię jako instrument polityki narodowej, krytykował pogląd o etycznym charakterze ekonomii, przekonanie ,jakoby dzięki pracy nauki ekonomii narodowej nie tylko znacznie rozszerzono poznanie istoty wspólnot ludzkich, lecz także jakoby stworzono całkiem nowe kryterium ostatecznego wartościowania zjawisk, jakoby ekonomia polityczna była w stanie pozyskiwać swe szczególne ideały z własnego materiału badawczego" (Weber 1958: 16). Czytelnik może zapytać, czy nie stoi to w sprzeczności z deklarowanym później przez Webera sprzeciwem wobec głoszenia w nauce wartości politycznych, wyraźnie zaakcentowanym zwłaszcza w memorandum Der Sinn der Wertfreiheit der soziologischen und ökonomischen Wissenschaften z 1917 roku (1988c). Weber zmieniał z czasem poglądy polityczne, co zapewne miało wpływ na jego rozumienie polityki jako takiej. W wykładzie freiburskim politykę utożsamiał 
nie z opowiadaniem się za określonymi ostatecznymi wartościami, lecz z „odpowiedzialnością”, a więc liczeniem się ze skutkami własnych działań, w tym polityki gospodarczej. W tym sensie wykład freiburski zawiera też zapowiedź koncepcji „etyki odpowiedzialności”. Zawiera w gruncie rzeczy dużo więcej niż, jak pisze Wolfgang Schluchter, „demoralizację ekonomii" w celu uczynienia jej nauka polityczną (Schluchter 1991: 178). Wskazuje bowiem również na to, że opisując konsekwencje przyjęcia takich a nie innych wartości, nauka może być narzędziem krytyki wartości. Innymi słowy, fakt, że nie może wartości uzasadniać, czyli orzekać, co jest dobre, na podstawie wiedzy doświadczalnej, nie oznacza, że nie może demaskować ludzkiej niewiedzy o wartościach.

Krytyka wartości nie może dotyczyć działań określanych przez Webera jako racjonalne ze względu na wartości (wertrational), a więc takich, które uważane są za dobre same w sobie, a nie ze względu na to, że prowadzą do szlachetnego celu. Uczony może bowiem stwierdzić, że dany środek w danych warunkach wcale nie prowadzi do pożądanego celu - może to orzec, odwołując się do wiedzy indukcyjnej i nie przesądzając wcale, czy cel rzeczywiście jest godny pożądania. Nauka jest więc władna uczynić całkiem sporo: określić możliwe skutki działania, możliwości realizacji danego celu, porównać różne wartości z punktu widzenia ich możliwych skutków i szans realizacji, a także kosztów, czyli stopnia naruszenia pewnych wartości w procesie realizacji innych. Nauka może wreszcie być pomocna, dostarczając wiedzy o samych wartościach, na przykład pomagając ludziom uświadomić sobie, jakie w ogóle mają wartości i czy wartości te posiadają kolejne ostateczne założenia, oraz sprawdzać realnie istniejące systemy wartości z punktu widzenia ich niesprzeczności.

Istotną cechą wartości jest to, że są przedmiotem ludzkich doświadczeń. Wiążą się ze szczególnym, osobistym uczuciem zobowiązania, „bycia głęboko przekonanym”. Wzorcem wyznania wartości może być luterańska formuła „Tu stoję i nie mogę inaczej”, wobec której Weber wyraża głęboki szacunek w Politike als Beruf, zwracając jednocześnie uwagę na rzadkość autentycznego, a więc odpornego na apele i pokusy przywiązania do wartości (Weber 1992: 80-81) . Doświadczenie wartości jest zatem czymś,

\footnotetext{
${ }^{4}$ Szacunek Webera dotyczy jednak tylko tych dojrzałych polityków, którzy po rozpatrzeniu wszystkich argumentów na rzecz i przeciwko podejmowanej decyzji, stają ostatecznie po stronie wartości, poświęcając często własną korzyść: „Jest to coś naprawdę ludzkiego i zachwycającego" (1992: 81). Jak dalej pisze Weber, to szczególne uczucie musi być choć raz udziałem każdego, kto nie jest „,wewnętrznie martwy”. Właśnie ta specyfika doświadczenia wartości decyduje o „zrozumiałości” etyki sumienia. Jako taka nie może być to jednak etyka idiosynkratyczna. Szerzej o intersubiektywnym doświadczeniu wartości por. znakomitą książkę Hansa Joasa (2009).
} 
co można „rozumieć”. Ktoś, kto czuje się przywiązany do wartości, posiada nie tylko wspomnienie idiosynkratycznego przeżycia, lecz zdolny jest do jego wyrażenia i jednoczesnego zdystansowania się wobec swych uczuć, by móc bronić wartości za pomocą argumentów. Istotą wartości nie jest zatem subiektywne przeżycie, „odczucie”, lecz proces myślowy, którego charakterystyczną cechą jest roszczenie do obiektywności poglądu, mówiącego, że coś jest dobre, oraz ukierunkowanie na dobro. Ukierunkowanie to nie oznacza tylko poszukiwania, lecz przede wszystkim interpretację życia i świata w kategoriach wartości. Innymi słowy, sa one tym, co nadaje życiu i światu sens (Weber 1988b: 152).

Roszczenia do obiektywności epistemicznej, intersubiektywności (w sensie wzajemnej zrozumiałości) i niezmienności wartości nie należy mylić z tym, jak wartości jawią się uczonemu, historykowi czy socjologowi. Widzi on ich stronniczość, subiektywizm (nieprzekładalność) i przede wszystkim zmienność. Między roszczeniem podmiotu doświadczającego wartości a roszczeniem uczonego do prawdy historycznej istnieje więc pod tym względem swoiste napięcie. Uczony musi jednak skapitulować wobec faktu, że nauka sama jest wyrazem wartości, do których jest odniesiona, i stanowi produkt kultury. Jej pojęcia i metody wymagają szeregu założeń, które przyjmowane są zwykle jako oczywiste, a w naukach o kulturze status takich założeń mają również liczne prawdy dotyczące praktycznych aspektów życia codziennego, których problematyczności nie widzimy tylko ze względu na ich powszechną akceptację.

Roszczeniowy, ostateczny i intersubiektywny charakter wartości najlepiej w istocie tłumaczy, dlaczego są przedmiotem zaciekłych sporów. Jak pisze Weber, za wartościami nie zawsze kryją się tylko interesy, nawet jeśli wiele konfliktów interesów da się zdemaskować za pozornymi walkami religijnymi czy ideologicznymi. Weber nazywa to zjawisko „pokrewieństwem wyboru" (Wablverwandtschaft) pomiędzy wartościami a interesami. Wszakże im ogólniejszy jest problem praktyczny, a więc im poważniejsze jego znaczenie kulturowe, w tym mniejszym stopniu można go rozwiązać, posługując się wiedzą doświadczenia. Interesy sprzyjają więc wyborowi wartości, gdy chodzi o sprawy własnego lub rodzinnego majątku, ale problemy ogólnospołeczne wywołują autentyczne kolizje światopoglądów. A zatem, gdy korzyść własna nie przesłania nam wartości, widzimy wyraźniej obiektywny charakter własnych roszczeń do ważności wartości, po stronie których się opowiadamy. Ponieważ dobro, na które ludzie się orientuja, jest niezależne od wartości kulturowych zniekształconych miłością własną i codziennymi przekonaniami, nie jest też możliwe wydedukowanie tych wartości z ogólnych norm etycznych; ideały odbiegają od 
powinności. Zasadę tę zdolne sa przełamać jedynie dogmatyczne sekty nadające treściom kulturowym rangę bezwzględnego nakazu etycznego. Te wyjątki, będące raczej rodzajem „kontrkultury”, potwierdzaja jednak tylko niemożność naukowego wyprowadzenia wartości z doświadczalnej wiedzy o społeczeństwie. W tym sensie wartości ostateczne są ontologicznie subiektywne, nie należą do świata poznawalnego naukowo, a „los epoki kulturowej, która jadła z drzewa poznania, polega na tym, że musimy wiedzieć, iż nie możemy wyczytać sensu tego, co się dzieje w świecie, z pełnego nawet wyniku jego przebadania, lecz musimy być w stanie ten sens sami stworzyć, musimy wiedzieć, że «światopoglądy» nigdy nie mogą być wytworami postępu wiedzy doświadczalnej" (Weber 1988b: 154).

Co to znaczy, że mamy „sami stworzyć” sens świata? Czy oznacza to coś więcej niż to, że sens ów nie jest empiryczny i nie może być po prostu dany w wynikach badań naukowych? Jeśli mamy sami określić sens, a więc ustanowić wartości i pozostać w zgodzie z cechującym je roszczeniem do powszechnej ważności i intersubiektywnej zrozumiałości, to bez wattpienia nie możemy zadowolić się stworzeniem ich tylko dla siebie, musimy uzgodnić „swoje” wartości ze stworzonymi przez innych, opanować sztukę kompromisu. Właśnie to rozwiązanie Weber odrzuca jednak expressis verbis $\mathrm{w}$ akapicie następującym po zdaniu o samodzielnym ustanawianiu sensu (1988b: 154-155). Rozwiązanie takie, pisze Weber, byłoby forma relatywistycznego ukrycia swych rzeczywistych wartości, zdrada gorszą niż obrona ich „dowodliwości”. Jak twierdzi Weber, trzeba mieć odwage występowania w obronie swych wartości, natychmiast jednak dodaje, że argumentacja na rzecz wartości odnosić się może tylko do „uczuć" i jako taka nie może osiagnać tego, do czego zgłasza roszczenie - powszechnej ważności (Geltung). Tę ostatnią będą mogły mieć zawsze tylko prawa naukowe. To one będa ,mogły być uznane za słuszne przez Chińczyka” (1988b: 155), który nawet po odrzuceniu wartości, które kierowały europejskim uczonym, będzie mógł przeprowadzić ich logiczna analizę i zredukować do ostatecznych aksjomatów.

Rozważania Webera zdają się prowadzić do wniosku, że roszczenie do obiektywności zrodzone przez doświadczenie wartości nie może zostać zrealizowane i pozostaje ściśle przestrzegać zasady oddzielenia sądów wartościujących od sądów poznawczych, aby nie stwarzać wrażenia, że jakikolwiek uczony może kiedykolwiek empirycznie uzasadnić wartości. Wniosek taki łatwo prowadzi do standardowej interpretacji kolejnych akapitów artykułu Webera (1988b: 156-157) jako wyłożenia dwóch obowiązków uczonego składających się na realizację zasady wolności od sądów wartościujących. Sądzę jednak, że możliwa jest odmienna interpretacja 
tego fragmentu, jeśli tylko rozumieć go jako dalszy opis drogi poznania wartości. Tuż wcześniej czytamy wszak: „...dalecy jesteśmy od błędnego przekonania, jakoby rozważania nad życiem kulturowym, które wykraczając poza myślowy porządek tego, co empirycznie dane, starają się interpretować świat metafizycznie, nie mogły spełnić swego zadania w służbie poznania jedynie ze względu na ten swój charakter" (1988b: 156). Dodaje wprawdzie, że sam takiej próby nie podejmie, ale nie odmawia jej zasadności. Wynika to z postulatu występowania na rzecz swoich wartości, a skoro nie można uzasadnić ich empirycznie, należy próbować innych dróg. Sądzę, że sam proponuje dalej jedną z nich.

Droga ta rozpoczyna się, podkreślmy, od przyzwolenia na wyrażanie sądów wartościujących w piśmie naukowym (tamże). Następnie Weber formułuje zalecenie ,jawności wartości”, czyli ich wyraźnego uświadomienia swym odbiorcom. W kolejnym kroku, zamiast uzasadnienia, a więc tego, co zwykle czynia zwolennicy wartościowania w nauce, proponuje realizację swego postulatu poszukiwania wiedzy w faktach i ich myślowym uporządkowaniu. Domaga się mianowicie poszukiwania założeń kryjących się za precyzyjnie wcześniej wyłożonymi wartościami (welches die Maßstäbe sind [...] aus denen das Werturteil abgeleitet wird). Sa to zarazem kryteria oceny rzeczywistości, a więc przesłanki poznania naukowego, nie tylko sądów wartościujących. Różnica między sądem wartościującym a poznawczym leży tu jak na dłoni - ten pierwszy polega na dedukcji twierdzenia z założenia, którego się nie podważa, drugi zaś na zakwestionowaniu założenia i poszukiwaniu jego własnych założeń. Przykładem jest dla Webera krytyka prawodawstwa. Wartościująca polega na przeciwstawieniu wartościom leżącym u podstaw projektowanej ustawy własnego systemu wartości o równie niezachwianych założeniach. Poznawcza - na poszukiwaniu motywów kryjących się za projektem, możliwych odniesień do wartości i wreszcie założeń leżących u podstaw tych wartości.

Ujawnienie wartości i ich założeń często nie wystarcza do ich poznania, nawet jeśli przybierają zrozumiała formę. Kolejnym krokiem procedury proponowanej przez Webera jest konfrontacja różnych wartości własnych i cudzych (1988b: 157). Ważne jest przy tym, że do zrozumienia wartości konieczne jest wspomniane wcześniej przy analizie „rozumienia” zachowanie własnej wartościującej perspektywy. Wartość nigdy nie jest zawieszona w próżni, zawsze jest czyimś wyborem, orientacją życiowa, ustosunkowaniem się do świata, standardem jego interpretacji z ,antropocentrycznej perspektywy”. Konfrontacja może i powinna odwoływać się do argumentów: do uczuć lub rozumu. W tym ostatnim wypadku będzie nauką. Zalecenie Webera, by nie mieszać ze sobą argumentów apelujących 
do uczuć z tymi, które odwołują się do rozumu, jest w zarysowanym tu kontekście jedynie powtórzeniem wniosku z artykułu Roscher und Knies, mówiącego, że „wczucie się” nie jest źródłem prawdy naukowej, ponieważ uzyskuje znaczenie dopiero jako myślowo przetworzone, logicznie zobiektywizowane „doświadczenie”. Każdy uczestnik konfrontacji wartości musi więc być gotowy na poddanie się ostrej rzeczowej krytyce.

Zdystansowanie się wobec własnych uczuć odgrywa nie tylko funkcję czysto poznawcza, lecz także, jak zauważa Weber (1988b: 158), zwiększa solidarność społeczności uczonych, którzy mają szansę na dyskusje pozbawiona burzliwych apeli do „zmysłu moralnego”. Ta niezwykle pozytywna społeczna konsekwencja „zasady wolności od sądów wartościujących", sprzyjająca integracji środowisk naukowych, ma też jednak mniej widoczny, ale niezwykle znaczący skutek w postaci odniesienia do wartości za sprawą kształtowania się w świecie uczonych specyficznych szkół myślowych, klimatu intelektualnego i bliskości duchowej. Te czynniki nadają ton ich działalności i szczególny charakter pismom naukowym i uniwersytetom. Sprawiaja, że uczeni stają się przywiązani do swoich sposobów selekcjonowania elementów rzeczywistości i absolutyzacji założeń własnych nauk. Czasem odniesienie do wartości powstaje za sprawa problemów praktycznych stanowiących inspirację czy zarzewie problemów badawczych, na przykład kwestia robotnicza w wypadku „Archiv für Sozialwissenschaften”. Weber jest świadomy faktu, że odniesienie do wartości jest więc nieuniknione w dwójnasób - ze względu na rolę w formułowaniu wyjaśnień naukowych oraz z uwagi na procesy zachodzące w świecie uczonych. Jego obrona kapitalizmu, jak sam pisze, nie jest oparta na absolutyzacji własnych założeń, a jedynie na tezie o nieuniknionym charakterze tego ustroju. Nie przeczy więc wcale obecności ukrytych wartościowań we własnej socjologii, choć zachowuje „wolność od sądów wartościujących”. Ten wniosek każe zaś ponownie postawić pytanie o możliwość „obiektywnej ważności prawdy” w naukach społecznych.

Aby rozstrzygnąć tę kwestię, Weber odwołuje się do konkretnego przykładu badań naukowych, mianowicie do ekonomii politycznej będącej również przedmiotem „Archiv für Sozialwissenschaften”. Zastanawia się nad natura przedmiotu tej nauki i definiuje najpierw główny problem ludzkiego działania, do którego się ona odnosi. Zwraca uwagę, że ów problem, czyli brak wystarczających zasobów, nie przejawia się w konkretnych procesach społeczno-ekonomicznych jako coś obiektywnego, lecz zależy od kierunku interesów poznawczych, te zaś od znaczenia kulturowego przypisywanego owym zjawiskom w danym momencie historycznym. Określenie przedmiotu badań ekonomii jest zatem względne, ponieważ 
zależy od tego, czy danemu procesowi lub zespołowi procesów, normom i instytucjom przypisuje się znaczenie kulturowe ze względu na ich aspekt ekonomiczny (brak zasobów). Przedmiot badań nie jest obiektywnie dany, lecz dany zawsze ze względu na punkt widzenia przyjęty przez badacza. Wśród tak określonych obiektów ekonomii można wyróżnić dalsze podkategorie: procesy ściśle ekonomiczne, czyli takie, których powstanie wiązało się ze świadomym celem o charakterze ekonomicznym, zjawiska istotne ekonomicznie, czyli takie, których nawet niezamierzone skutki są ważne z punktu widzenia braku zasobów i wreszcie zjawiska uwarunkowane ekonomicznie, czyli takie, które powstały między innymi ze względu na motywy ekonomiczne, choć nie musiał to być główny cel ich powstania. Nauka, wedle charakterystyki Webera, wychodzi więc od dostrzeżenia problemu, następnie odnosi go do sfery zjawisk, które określa na trzy różne sposoby: jako cel, przyczynę lub skutek. We wszystkich wypadkach zjawiska są jednak tylko przejawem działania ludzkiego, które ukierunkowuje się na wspomniany wyjściowy problem. Innymi słowy, „zjawiska” społeczne sa „obiektami” tylko w takim znaczeniu i zakresie, jaki wynika z wyjściowego problemu i to nie tylko dlatego, że problem ten oceniany jest jako istotny przez samego badacza, ale także dlatego, że aspekt ekonomiczny zjawisk (pozwalający na wyodrębnienie przedmiotów ekonomii) to tyle, co cele, przyczyny lub skutki działania ukierunkowanego na problemy ekonomiczne. Znaczenie kulturowe nie jest zatem wyłącznie „konstrukcja”” uczonego, lecz także podmiotów działania, a dalej samej kultury, którą bada. Ponieważ jednak sam wyjściowy problem również nie jest „uniwersalny”, to cała wiedza naukowa może być uznana za względną wobec wartości.

Ani uczeni, ani zwłaszcza badani przez nich ludzie, zanurzeni w swoich kulturach, nie są raczej skłonni dostrzegać względności najbardziej stabilnych założeń kulturowych, którymi kierują się w swoich działaniach. Stąd też Weber proponuje zawężająca procedurę badawczą, rozpoczynająca się od identyfikacji motywów służących jako kryterium przedmiotowe, czyli, w ekonomii, od orientacji na korzystanie z ograniczonych środków zewnętrznych, przez przypisanie kulturowych zjawisk ekonomicznych indywidualnym przyczynom, aż po identyfikację ekonomicznego aspektu danego zjawiska w jego konkretnym znaczeniu kulturowym. Taka ekonomiczna interpretacja historii nie stanowi jeszcze poznania naukowego w pełnym tego słowa znaczeniu. Jest jedynie pracą wstępna pozwalająca dostrzec względność punktów widzenia, które mogą wchodzić w grę przy próbie wyjaśniania danego zjawiska. Świadomość, że uzyskany obraz jest cząstkowy, sprawia, że inne, powiązane obszary ujawniaja swe związki z problemem ekonomicznym, rodzą więc nowe pytania i każą 
kwestionować niepodważane dotąd założenia. Znaczenie czynnika ekonomicznego jako przyczyny czy skutku nie musi być wszak problematyczne za każdym razem, a tylko w takim wypadku Weber pisze o istnieniu „problemu społeczno-ekonomicznego” (1988b: 164).

Znaczenie kulturowe jest zatem punktem widzenia, który konstytuuje nauki o kulturze i odgranicza je od innych. Kryterium tego odróżnienia nie jest rzeczowe, lecz myślowe, podobnie jak kryterium wyodrębnienia obiektu. Kultura różni się pod tym względem od „tego, co społeczne”, wszak stosunki między ludźmi obejmują najróżniejsze możliwe treści, nie są w żaden sposób określone. Do tego, by stały się obiektami badań, konieczna jest myślowa abstrakcja, dostrzeżenie związków między problemami, zamiast związków między rzeczami. Formułowanie związków rzeczowych jest bowiem pochodną myślowej abstrakcji. Stąd też nauka o społeczeństwie niebędąca zarazem badaniem znaczeń kulturowych jest niemożliwa. Jak pisze Weber, „to, co «ogólne» [w pojęciu tego, co społeczne] nie opiera się na niczym innym, jak właśnie na nieokreśloności tego pojęcia. Jeśli brać je w jego «ogólnym» znaczeniu, to nie dostarcza żadnych specyficznych punktów widzenia, które mogłyby naświetlić znaczenie określonych elementów kulturowych" (1988b: 166).

Skoro już wiemy, w jaki sposób problemy badawcze w naukach społecznych prowadzą do rozpoznania „zjawisk kulturowych”, musimy zapytać, jak można wyjaśnić same te zjawiska. Pierwsza narzucająca się opcja to możliwość ich wydedukowania z pojęć bardziej ogólnych. W szczególności czyniono tak, wyprowadzając zjawiska kulturowe z układów interesów. Weber kładzie duży nacisk na różnicę między ekonomiczną interpretacją historii, mającą na celu wskazywanie różnych powiązań danego zjawiska kulturowego z punktu widzenia problemu ekonomicznego, a jednostronnym wynoszeniem interesów ekonomicznych (czy jakichkolwiek innych) do rangi jedynej czy ostatecznej przyczyny wszelkich zjawisk. Gdy własne, specyficzne założenia danej nauki, wynikające z problemowego punktu widzenia, awansują do rangi zasad świata, wiedza fachowa zmienia się w światopogląd, a metoda indukcyjna ustępuje dedukcji. Monizm takich wyjaśnień wynika z absolutyzacji założeń własnej dziedziny wiedzy, braku świadomości ich względności. Tak więc, według Webera, sprowadzanie zjawisk kulturowych do „interesów” czy „rasy” to nic innego jak „dokumentacja niewiedzy” wąsko wyspecjalizowanych uczonych lub przejaw ich "patriotyzmu resortowego" (Weber 1988b: 167-169). Jednostronne wyjaśnienia prowadza zawsze do tendencyjnej nierównowagi w przypisywaniu przyczyn i traktowaniu odchyleń jako „przypadku”. 
Czy jednak jednostronności można w ogóle uniknąć, skoro, jak ustaliliśmy wcześniej, wszelkie wyjaśnienie od początku zależne jest od obranego lub nieświadomego „punktu widzenia”? Nie ulega wattpliwości, że Weber odrzuca możliwość zarówno epistemicznej, jak i ontologicznej obiektywności poznania naukowego z uwagi na to, że rzeczywistość badana jest zawsze „czyjąş” rzeczywistością, a ów antropocentryzm dotyka już samych początków wszelkiej pracy badawczej w postaci odniesienia do wartości. Powraca więc wyjściowe pytanie tekstu o to, co oznacza „obiektywność” nauki. Nowa próba odpowiedzi musi już jednak uwzględniać wniosek, że cała rzeczywistość zjawisk kulturowych jest rzeczywistością człowieka i jest możliwa do zrozumienia i wyjaśnienia tylko ze względu na specyfikę znaczeń kulturowych, które ją konstytuuja. Nie oznacza to, że nie jest możliwe poznanie formalne, ale jest zbyt nieokreślone, by umożliwiać przypisywanie konkretnych przyczyn do konkretnych procesów. Gdy tylko uczony podejmie próbę wyjaśnienia danego zjawiska z uwzględnieniem wszystkich jego indywidualnych składowych i powiązań przyczynowych, to wyjdzie na jaw wspomniana „absolutna nieskończoność różnorodności”, przeszkoda obiektywności poznawczej, która sama pozostaje obiektywna niczym Kantowska „rzecz sama w sobie". Zasada poznania naukowego jest więc selekcja. Pytanie brzmi, czy kieruje się ona jakimikolwiek zasadami.

Dwie typowe odpowiedzi, jakie można znaleźć także we współczesnej teorii nauki, wskazują na indukcję i dedukcję jako zasady selekcji. Według Webera obie jednak zawodza. Indukcja pozwala wprawdzie stwierdzać prawidłowości (powtarzalność) faktów, ale, pomijając okoliczność, że samo określenie faktów wymaga selekcji, regularność nie dostarcza wyjaśnienia dla tego, co nie podlega prawidłowości, a tymczasem to właśnie interesuje badacza z uwagi na swe znaczenie kulturowe i wyjątkowość. Poszukiwanie coraz głębszych (biologicznych, fizycznych) prawidłowości zawsze musi polegać na wyjaśnianiu indywidualnych przyczyn indywidualnego stanu rzeczy, który ma dla nas określone znaczenie. Poszukiwanie ostatecznych przyczyn prowadzi do wyobrażenia „stanu początkowego”, z którego można by wydedukować dalsze fakty. Tego jednak właśnie nie da się uczynić, ponieważ „w poznaniu rzeczywistości chodzi nam o znalezienie układu, w który grupują się owe (hipotetyczne!) «czynniki», tworząc znaczące dla nas historycznie zjawisko kulturowe, i ponieważ chcąc ten indywidualny układ wyjaśnić przyczynowo, musimy odnosić się do innych, tak samo indywidualnych układów, za pomocą których wyjaśnilibyśmy go, korzystając z owych (hipotetycznych!) pojęć-«praw»” (1988b: 174). 
A zatem z krytycznej analizy Webera wyłaniają się trzy kryteria selekcji. Po pierwsze, nauki o kulturze sa zainteresowane indywidualnym kształtem zjawisk (ich rysem jakościowym), który określają ale sam nigdy nie może być do końca określony. Po drugie, badaja one procesy psychiczne, za sprawą których dochodzi do wspomnianego ,jakościowego nacechowania” rzeczywistości. Po trzecie wreszcie, starają się ,zrozumieć” owe procesy, aby uchwycić ich sens i móc wydobyć zjawiska przyczynowe z otchłani nieokreśloności. Cała opisywana tu procedura badawcza wymaga uporządkowania czynności. Rozpoczyna się od zidentyfikowania możliwie różnych czynników składających się na ,znaczące zjawisko kulturowe". Następnie wymaga odwołania się do praw indukcyjnych, umożliwiających przypisanie tej grupy czynników do innej indywidualnie wyróżnionej grupy czynników. W trzecim kroku następuje próba „zrozumienia" znaczenia kulturowego w jego ustalonych już powiązaniach. Wreszcie na koniec uczony śledzi przyczyny konkretnych szczególnych cech stwierdzonych wcześniej (skonstruowanych) układów czynników.

Opisana tu pokrótce procedura dowodzi, że wyjaśnienie przyczynowe możliwe jest tylko przez odniesienie do wartości, które stanowia rzeczywistość całkiem odrębna od tej opisywanej przez generalne prawa posługujące się ogólnymi pojęciami. Nie można jej wyprowadzić z żadnego systemu tych pojęć i to tym bardziej, im bardziej ogólny jest to system. Wzrost zakresu pojęć oznacza dla nauk o kulturze utratę treści. Różnica między pojęciami odnoszącymi się do wyjątkowości zjawisk a pojęciami generalnymi jest odzwierciedleniem zawieszenia ludzkiej rzeczywistości między czystą formą praw a odniesieniem do wartości. Pojęcia mają więc zaledwie status środków poznania. Zarazem trzeba jednak pamiętać o tym, że znaczenia kulturowe wyrażone w pojęciach mogą same być faktami historycznymi. Pojęcia naukowe i znaczenia kulturowe nie odpowiadają więc sobie do końca, gdyż istnieją osobno i cały czas podlegaja zmianom, a te są od siebie zależne jedynie w ograniczonym stopniu. Zrozumienie natury tej relacji jest przedmiotem szczególnej uwagi Webera. Czym jest jednak rzeczywistość znaczenia kulturowego, której nie można ująć w pojęciach ogólnych? Jak zrozumieć to, co określa, ale samo nie jest do końca określone?

Odpowiedź na powyższe pytanie jest jak na razie negatywna. Nie można zdobyć w żadnym sensie obiektywnej wiedzy o owej rzeczywistości, próbując ją wyprowadzić z ogólnych praw psychologii czy z metafizycznego systemu pojęciowego. Chociaż procesy kulturowe przebiegaja zgodnie z prawami nauki (wykazuja prawidłowości uchwytne dla metod indukcyjnych), to nie sa możliwe do wyjaśnienia przez same te prawa. Subiektywizujący punkt widzenia wskazuje, że rzeczywistość, 
o której mowa, ukonstytuowana jest przez znaczenie kulturowe. Znaczenie to przysługuje jednak zawsze tylko pojedynczym stosunkom, to one stanowia , indywidua historyczne”. Te zaś wynikaja z wartości, z punktu widzenia których rozpoczynamy poznawanie świata. Kultura obejmuje więc zawsze tylko wycinek bezsensownej nieskończoności stawania się świata, a mianowicie ten, któremu nadajemy sens. To on jest nasza rzeczywistością. Jej istnienie, sens i zmiana wynikają zawsze $z$ naszego ukierunkowania na wartości, na idee dobra, które nam przyświecają. W tym sensie „kulturą” jest wszelka sensowna dla nas rzeczywistość, nawet „powrót do natury”. Odniesienie do wartości nabiera tym samym znaczenia wykraczającego daleko poza to, czym wydawało się początkowo, poza przygodną okoliczność badania naukowego, część uwarunkowań procedury badawczej czy też wreszcie wybór takiej czy innej kultury lub idei. Odniesienie do wartości jest istotą naszego istnienia. Konstytuuje nas jako myślących ludzi, a także całą naszą rzeczywistość, choć ta ostatnia wyłania się w nieustannym procesie nadawania znaczenia indywiduom historycznym, wyodrębniającym się z nieskończoności złożonych łańcuchów przyczynowych: „Transcendentalną przesłanką wszelkiej nauki o kulturze nie jest to, że uważamy jakąś określoną czy w ogóle jakąkolwiek «kulturę» za wartościowa, lecz to, że jesteśmy ludźmi posiadajacymi kulturę [Kulturmenschen], wyposażonymi w zdolność i wolę świadomego ustosunkowywania się do świata i nadawania mu sensu" (1988b: 180).

Weber interpretuje nadawanie światu sensu przez wartości jako aktywność ludzką, procesy poznania i wartościowania są więc, według niego, ściśle ze sobą związane w tym sensie, że proces poznawczy dokonuje się $z$ aktywnym udziałem podmiotu, podobnie jak wartościowanie. Skoro to my wartościujemy, skoro wartości pochodzą od nas, czy też, mówiąc inaczej, są wyrazem naszego punktu widzenia, to nie moga być „odkryte” w świecie czy wyprowadzone z systemów pojęciowych. Z tej suwerennej pozycji wartości wobec świata i jego nieustannej przemiany wynika antyrelatywizm Webera. Wartości nie są względne wobec kultury, struktury interesów czy sytuacji politycznej, gdyż to one konstytuuja wszelkie znaczenie kulturowe. Istniejąca struktura norm i instytucji nie pozwala też na „odczytanie” leżącego u jej podstaw systemu wartości, gdyż danej strukturze instytucjonalnej może odpowiadać bardzo różny porządek wartości albo innymi słowy, różne porządki wartości mogą być wyrażone i realizowane w różnych strukturach, na przykład uspołecznienie środków produkcji może dokonać się w systemie indywidualnych praw do własności (1988b: 183). Stąd też zawodne są teleologiczne wyjaśnienia socjologiczne. Rozumienie celów może odegrać rolę naukową tylko 
w wypadku, gdy wyobrażenie skutków działania jest jego przyczyna (a więc przy zastosowaniu schematu działania celoworacjonalnego).

Wiemy zatem, że rzeczywistość odniesienia do wartości ma charakter fundamentalny, ponieważ konstytucja rzeczywistości przez wartości jest założeniem wszelkich procesów poznawczych. Nie oznacza to jednak, że możemy wyjaśnić same wartości ani tym bardziej rozstrzygnąć kolizje między nimi. Nasz stosunek do wartości określa Weber jako , wiarę” (1988b: 182). Ów pierwotny akt wiary podmiotu rozciaga się na cała rzeczywistość. Zasady dowodzenia, logicznego porządkowania faktów znajdują zastosowanie jedynie wewnątrz owej rzeczywistości ustanowionej przez akt wiary, ale nie do samego fundującego aktu. Podobnie bezużyteczne w roli eksplanacyjnej są zamknięte systemy pojęciowe. Żadne uporządkowanie faktów za pomocą takich systemów nie będzie pełne czy ostateczne, ich ograniczenia odzwierciedlają ograniczenia samego badacza. Tak jak on czerpia one swe znaczenie i kumunikowalność z kultury, w której badacz jest zanurzony; podobnie jak jego myśli i odniesienia zmieniają się, raz próbując adekwatnie oddać specyfikę zjawisk kulturowych, a kiedy indziej ujmować je w ogólne formuły w celu dokonania porównań i rozszerzenia wiedzy. W pojęciach stosowanych przez uczonych nader widoczna jest zatem permanentna nieadekwatność rzeczywistości zastygłej w pojęciach wobec płynnej kultury, która sama nieustannie tworzy pojęcia i zmienia ich sens. Odniesienie do wartości, oprócz tego, że pozwala na poznanie zjawisk kulturowych, samo też jest problemem społecznym, wymaga intersubiektywnej pracy myślowej. Weber opisuje jej uwarunkowania, korzystając z pojęcia „typu idealnego”. Wokół definicji tego wyrażenia wiele już dyskutowano, widząc w typie idealnym przede wszystkim środek heurystyczny. Warto jednak zwrócić uwagę, że w rozważaniach Webera typ idealny rozpatrywany jest jako element szerszego systemu pojęciowego, odnoszącego się do zjawisk kulturowych i stanowiącego samemu integralną ich część. Autorefleksyjność, która go cechuje, jest nieodłączna od wszelkiej refleksji społecznej już na poziomie pojęciowym, a więc nim jeszcze dojdzie do formułowania zasad metodologicznych, twierdzeń, generalizacji czy praw. Odniesienie do wartości występuje już na poziomie wyboru i tworzenia pojęć, stąd zbadanie natury systemu pojęciowego jest ostatnim etapem metodologicznego wątku rozważań Webera. Zarazem pozwala też na domknięcie argumentacji na rzecz wolności od sądów wartościujących przez wskazanie roli tej zasady w procesie poznawczym.

Główne zainteresowanie Webera nie kieruje się na wyizolowane pojęcia ani nawet na systemy pojęć, lecz na tworzenie pojęć na potrzeby teorii, a więc na proces budowy teorii $\mathrm{w}$ naukach o kulturze, a w szczególności 
w ekonomii politycznej. Punktem wyjścia jest oświeceniowy, racjonalistyczny model rozważania wszystkich zjawisk z jednego, praktycznego punktu widzenia - tworzenia i pomnażania bogactwa obywateli. Ów techniczny sposób pojmowania nauki stanowił, według Webera, część całościowego prawnonaturalnego światopoglądu XVIII stulecia. Cechujące go racjonalizm i monizm przesłaniały, jak pisze Weber, wartościujący punkt widzenia leżący u ich podstaw. Ta niewidoczność założeń została jeszcze wzmocniona przez pokrewieństwo wiary $\mathrm{w}$ racjonalizację (odczarowanie) świata (Weber 1988d) z nowoczesnymi naukami przyrodniczymi. Ich założenie technicznej przydatności przez wieki nie było podważane ze względu na tradycję przejęta jeszcze od starożytnych. Nieświadomość własnych wartości doprowadziła, jak kontynuuje Weber, do monistycznego roszczenia wysuwanego przez ten światopogląd. Miał być oderwanym od wartości i w tym sensie „obiektywnym” systemem pojęciowym obejmującym cała rzeczywistość w formie ogólnych praw. Dla poszczególnych dziedzin technicznych, jak sztuka medyczna czy inżynieria budowlana, przewidywano zadanie stosowania ogólnej wiedzy, zakładając, że ich cele nie sa problematyczne. „Istota” obiektów nauki rozmywała się w zjawiskowości wyjaśnianej przez prawa, a uczeni nie odwoływali się do punktów widzenia nacechowanych wartościami. Ten „zmierzch bogów” zapowiadany przez oświeceniową wizję nauki przyrównuje Weber do Heglowskiego panlogizmu. Jak w tym ostatnim rzeczywistość miała odpowiadać pojęciu, tak w pierwszym pojęcie miało odpowiadać rzeczywistości. Indywidualne procesy mogły w monistycznym obrazie świata stanowić jedynie „typy” w znaczeniu reprezentantów praw, mogły je ilustrować, ale nie dodawały nic do rzeczywistości ujętej w matematyczne formuły.

Dla Webera indukcja i dedukcja zdają się więc dwiema stronami tego samego medalu, które jednak, jak pamiętamy, nie umożliwiają wcale poznania „rzeczywistości” w sensie Webera, a więc rzeczywistości naszego życia, sytuacji człowieka w świecie. Rzeczywistość przeżywana bezpośrednio, a nie pojęciowo, umożliwia rozumienie związków między indywiduami historycznymi, to zaś jest przesłanką zastosowania praw. Powiązania te sa tylko pomyślane i dopóki nie zostaną wyjaśnione przyczynowo, stanowia zaledwie możliwości i jako takie moga być przedmiotem idei historycznych. Idee nie zawsze maja charakter naukowy. Mogą jednak stać się środkiem poznania naukowego. Najpierw pozwalają na wyodrębnienie układów czynników, które podlegają wyjaśnieniu. Gdy zaobserwowane procesy uzyskują status faktów empirycznych, uczony wysuwa przypuszczenie o ich specyfice (Eigenart), która ponownie może być zilustrowana 
w postaci pojęcia. Takie właśnie refleksyjne pojęcie nazywa Weber „typem idealnym".

Refleksyjność nie oznacza w żadnym razie, że typ idealny zawsze stosowany jest świadomie. Jego istotą jest możliwość porównania tego, co dane empirycznie, do przypadku granicznego, zbioru cech pomyślanych jako charakterystyczne dla danego indywiduum historycznego. Jeśli historyk unika stosowania typów idealnych, to, jak pisze Weber, albo pozostanie w „nieokreśloności odczuwania”, albo będzie zdany na nieświadome stosowanie innych typów idealnych (1988b: 195). Typy idealne stają się więc nieuniknionym środkiem badawczym, gdy tylko dookreślamy rzeczywistość kulturową. Choć ich geneza wiąże się z występowaniem różnych pojęć w języku codziennym, to nie są tożsame ani z ideami kulturowymi (a więc przedmiotem historii idei), ani też z ich desygnatem. Nie są to realne zjawiska ani nawet to, co przeciętne, czyli wypadkowa cech różnych zjawisk. Z drugiej strony, ta sama idea może mieć wiele typów idealnych, na przykład typem idealnym własności może być zarówno Jeffersonowska wizja samowystarczalnych majątków ziemskich, jak i giełda finansowa w nowoczesnym mieście handlowym. Zarazem znaczenie kulturowe może być ujęte za pomocą wielu typów idealnych, na przykład nieposłuszeństwo obywatelskie może być określone za pomocą typu romantycznego lub demokratycznego (Kaczmarczyk 2010). Owa wielość środków heurystycznych, które teoretyk ma do dyspozycji, zwiększa się wraz z wielostronnością zjawiska kulturowego, mnogością jego powiązań. Co więcej, owe powiązania moga się także zmieniać, co można łatwo zilustrować choćby ewolucją idei liberalizmu. Zmiany typów idealnych moga, rzecz jasna, wynikać z historii idei, ale mogą też odzwierciedlać jedynie zmianę orientacji wartościującej badacza. Odniesienie do wartości jest immanentną cechą typu idealnego, ponieważ znaczenie kulturowe leżące u podstaw selekcyjnej funkcji typu idealnego jest implikacją jednej lub więcej wartości.

Umożliwiając porównania, typ idealny rozszerza istniejącą wiedzę, pozwala szukać wybranych aspektów danego zjawiska także w innych zjawiskach, porównywać doświadczenia i szukać adekwatnych zastosowań praw ogólnych. W pewnym sensie jest miarą rzeczywistości, wszak jej odchylenia od tego, co zawarte jest w typie idealnym, dają podstawę do tworzenia kombinacji różnych typów i oceny wagi odchyleń faktów empirycznych. Typ idealny jest zatem miara poznawczą, a nie miarą wartościująca, kryterium jego poprawności stanowi owocność teoretyczna, głębia rozumienia i możliwość formułowania nowych wyjaśnień. Nie jest natomiast opisem stanu pożądanego czy wartościowego. Dlatego też, jak pisze Weber, można mówić o typie idealnym burdelu równie dobrze jak o typie idealnym 
prawa czy religii (1988b: 200). Będąc narzędziem poznawczym, typ idealny przez samą wyraźność swej funkcji odcina zawarte w nim odniesienie do wartości od wartościowania. Wartość poznawcza typu idealnego nie wynika z samego rozszerzania zakresu ogólności formułowanych twierdzeń, lecz z adekwatności empirycznej cech specyficznych zawartych w pojęciu.

Gdy typ idealny przestaje być pojęciem służącym poznaniu, a staje się ideą władająca myślami ludzi danej kultury lub gdy od dawna jest taką idea, której incydentalnie tylko zdarzyło się wystąpić także w funkcji typu idealnego, wartościowanie niechybnie dochodzi do głosu. Tak na przykład „chrześcijaństwo” może być charakteryzowane jako całokształt cech różnych grup religijnych-ich poglądów, zwyczajów, losów-do których przyrównywać można praktyki i wierzenia konkretnych grup. Zarazem jednak dla wierzących to samo „chrześcijaństwo” mówi, co jest ideałem postępowania, wzorcem życia itd. Pojęcia te różni tylko funkcja w szerszym systemie pojęciowym. Pierwsze ma pozwolić na rozpoznanie „istoty” chrześcijaństwa i jego rozmaitych konotacji, drugie zaś na identyfikacje tego, co w chrześcijaństwie wzorcowe, jego elementów normatywnych. Pomieszanie obu pojęć staje się prawdopodobne zwłaszcza wtedy, gdy historyk chce znaleźć kryteria swych sądów we własnym materiale badawczym. Wówczas typy idealne stają się dlań pojęciami odnoszącymi się do tego, w co wierzyli sami uczestnicy wydarzeń historycznych, co stanowiło treść ich kultury. Porządek logiczny typów idealnych staje się z kolei odwzorowaniem historii idei (1988b: 204).

Łatwo można wszakże podnieść zarzut, że wywodzenie wartości z typów idealnych jest nieuniknione, skoro źródłem pochodzenia typów idealnych jest historyczna rzeczywistość podmiotów wartościujących. Weber pisze, że typy idealne są syntezami idei praktycznych ujawniającymi znaczące kulturowo układy czynników (1988b: 200-201). Co więcej, zawierają one nie tylko odniesienia do wartości, lecz również domyślne odniesienia do sądów wynikających z praw nauki. Tak na przykład pojęcie wymiany ekonomicznej zawiera sądy dotyczące typowych warunków wymiany (1988b: 202). Niezależnie od tych elementów typ idealny ma jednak na celu uwypuklenie specyfiki zjawiska kulturowego, nigdy nie abstrahując od cech szczegółowych, pozwalających na jego zrozumienie. Toteż utożsamianie typu idealnego z prawem historycznym, jak czynił to na przykład Jerzy Topolski (1984: 121), należy uznać za błąd uniemożliwiający nie tylko właściwe badawcze wykorzystanie metody Webera, ale i rozmywający kreatywistyczny wymiar historii $\mathrm{w}$ deterministycznych strukturach (pamiętajmy o społecznej genezie pojęć naukowych!). Nie jest przypadkiem, że ostatecznie Topolski expressis verbis klasyfikuje Webera jako przedstawiciela 
kierunku strukturalnego (tamże: 116, 125), nawet jeśli później zmuszony jest dostrzec u niego myślenie „kierunkowe” (tamże: 152).

Zachowanie odrębności typów idealnych od pojęć gatunkowych i praw nauki oraz, z drugiej strony, od żywych idei historycznych, pozwala na zachowanie szczególnego dystansu do rzeczywistości, ale tylko po to, by móc ją lepiej zrozumieć i dostrzec więcej aspektów jej złożoności. Dystans ten sprawia, że w sytuacjach, gdy obserwuje się w świecie daleko idące odchylenia od typu idealnego, można go poddać rewizji. Przykładem może być pojęcie „społeczeństwa rzemieślniczego”, które zorganizowane jest w taki sposób, że jedynym źródłem akumulacji kapitału jest w nim renta gruntowa (Weber 1988b: 191, 203). W wyniku oddziaływania możliwych do zidentyfikowania czynników, takich jak ograniczony areał gruntu, wzrost liczby ludności, napływ metali szlachetnych czy racjonalizacja sposobu życia (znana z Weberowskiej koncepcji „ducha kapitalizmu”), ów typ idealny przekształca się w typ „społeczeństwa kapitalistycznego”. Różnice między typem idealnym „społeczeństwa rzemieślniczego” a faktami skłaniaja do pytań, czy ów typ jest adekwatny, a więc czy badane społeczeństwo rzeczywiście jest rzemieślnicze i pod jakimi względami. Napięcie między typem idealnym a wynikami badań empirycznych jest więc siła napędowa nauk o kulturze, gdyż skłania do kierowania uwagi na te elementy obrazu faktycznego, które odbiegają od uprzedniej idealnej konstrukcji pojęciowej, i prowadzi do budowy nowych typów idealnych. Dojrzewanie nauk o kulturze oznacza więc nie tyle gromadzenie „teorii średniego zasięgu” w celu formułowania coraz ogólniejszych praw, ile przezwyciężanie typu idealnego między innymi przez demaskowanie elementów idealnotypologicznych w pojęciach gatunkowych i generalizacjach empirycznych (Weber 1988b: 206). Młoda filologia może wyobrażać sobie język jako ponadempiryczny zbiór norm stanowiących spójną całość. Badanie konkretnych języków polega wtedy na redukcji treści do wyobrażonych reguł składających się na typ idealny języka. Z czasem badacz dostrzega nieskończoną wielość języków lokalnych i indywidualnych, idiosynkrazje języka mówionego, a nawet nowe języki. Cały ten proces poznawczy rozpoczyna się jednak i jest ukonstytuowany za sprawą typu idealnego, nadającego mu kierunek i „miarę rozumienia”. Proces wyłaniania się nowych typów idealnych nie ma końca, ponieważ „wieczny jest płynny nurt kultury dostarczający ciągle nowych problemów” (tamże).

Warto podkreślić, że nakreślona przez Webera dynamika wiedzy, określona przez dialektykę pojęcia i przedmiotu, trwa dzięki wysiłkowi stałej konfrontacji różnych konstrukcji pojęciowych. Selekcyjność, wyrazistość i ogólność typu idealnego stają się zaletami dopiero wtedy, gdy 
uczony uświadamia sobie miejsce danego pojęcia w strukturze pojęciowej swej dyscypliny i w samym życiu społecznym - gdy zdaje sobie sprawę ze spektrum jego znaczeń kulturowych. O tym, jak zasadnicze znaczenie ma ta świadomość, świadczy przykład podany przez francuskiego historyka Henri-Irénée Marrou (2011: 158-159). Gdy opisywał on stworzony przez Numę Fustela de Coulanges'a typ idealny starożytnego miasta-państwa (polis), odróżnił ów typ pojęcia od realnych zjawisk, hipotez czy „predykatów uniwersalnych", aby podkreślić rolę indywidualnego, oryginalnego wkładu myślowego historyka. Zwrócił uwagę, że faktyczne istnienie podobnych konfederacji wielkich rodzin, zintegrowanych kultem przodka lub herosa, jest wysoce problematyczne empirycznie, pojęcie to jednak pozwoliło na wyróżnienie później przez Henri Jeanmarie szeregu innych typów, na przykład „miasta lecedemońskiego” czy „rodziny arystokratycznej”. W gruncie rzeczy właśnie to, co Marrou postrzega jako słabość metody Webera, a mianowicie jej konwencjonalność i względność, z której historyk ciagle zdaje sobie sprawę, jest też jej siła. Dowodzi tego właściwie sam Marrou, gdy wskazuje, że spór Victora Ehrenberga z Helmutem Berve w sprawie datowania polis przestaje być sporem, a staje się źródłem nowych konstrukcji pojęciowych, jeśli zauważyć, że stosują oni różne typy idealne polis, wywodzące się z różnych inspiracji praktyczno-teoretycznych. Warto zwrócić uwagę, że uczony może stać się świadomy względności własnej konstrukcji pod warunkiem świadomego odniesienia do wartości i przy zachowaniu obiektywności ontologicznej tego odniesienia. W przeciwnym razie stosowane pojęcia stają się dlań albo czystą fantazją literacka, albo ulegają absolutyzacji, czego dobrym przykładem są „pojęcia zbiorowe”, takie jak naród, „rolnictwo” (w znaczeniu wszystkich rolników) czy Kościól. W pojęciu „rolnictwa” zapoznawane są nie tylko konflikty interesów materialnych i idealnych różnych rolników, ale zarazem też heterogenne odniesienie do wartości samego badacza wyrażające się w określeniu „interesów rolnictwa” - w wyselekcjonowaniu tego, co sam badacz uważa za ważne dla (niektórych) rolników (Weber 1988b: 210-211). Względność indywidualnych interesów rozmywa się tu w nieświadomym stanowieniu wartości przez samego uczonego.

Odpowiedź na wyjściowe pytanie o możliwość obiektywnej wiedzy o kulturze i wartościach jest więc złożona. Z jednej strony, odniesienie do wartości jest ontologicznie obiektywne, wszak konstytuuje nasze istnienie jako ludzi. Lecz właśnie ów konstytutywny byt pozostaje w swej treści poza zasięgiem naszego poznania. Wypełniamy go bezowocnie treściami kulturowymi, przesłaniając sobie jedynie ich względny status. Z drugiej strony, założenia, w które musimy wierzyć, otwierają nam drogę do 
badań tego wszystkiego, na co rzucają światło poznania. Te badania, o ile są zgodne z regułami poprawnego, logicznego myślenia, mogą być obiektywne epistemicznie, to znaczy moga być intersubiektywnie akceptowalne i sprawdzalne za pomocą wspólnych reguł pracy naukowej. Owe badania nie moga jednak dotyczyć samej treści wartości. Nauka zaczyna się tam, gdzie kończy się wiara, wobec wiary musi zamilknać. W jaki więc sposób możliwa jest wiedza o wartościach? Otóż proces niewartościującego poznania wartości ukazuje nam dialektyka typu idealnego. Typ idealny jest pojęciem niechybnie odniesionym do wartości, wywodzącym się z tego, co w samej kulturze stanowi takie odniesienie. Zarazem jednak dystansuje się wobec tego odniesienia, traktując je nie jako założenie ontologiczne dalszych badań, lecz jako konstrukcję względną, założenie, które samo ma podlegać badaniom, które problematyzuje rzeczywistość tylko po to, by ulec dalszej problematyzacji. Typ idealny nie stanowi wartości ani nie pozwala im się wyłonić ze sfery noumenalnej, pokazuje nam jedynie iluzyjność ludzkich wartościowań i nigdy nie może zejść z tej drogi. Mówiąc inaczej, Weber ukazuje nam drogę do poznania dobra kryjącego się za wartościami, ale dobra tego nie definiuje.

\section{/// IV}

Wnioski Webera zawarte w tekście Die Objektivität sozialwissenschaftlicher und sozialpolitischer Erkenntnis nie oddalają nas w żadnej mierze od poznania wartości. Wolność od sądów wartościujących wpisana w konstrukcję typu idealnego okazuje się wręcz niezbędnym warunkiem tego poznania. Zacznijmy od tego, że Weber wyraża optymizm co do możliwości niewartościującego badania zjawisk kulturowych. Pisze, że w epoce rosnącej specjalizacji opracowywanie danego materiału historycznego można traktować jako cel sam w sobie bez konieczności oceny wartości poznawczej takiej pracy za pomocą kryteriów wartościujących (Weber 1988b: 214). Rozpoznanie i problematyzacja własnych wartości musza jednak w końcu nadejść: „...znaczenie bezrefleksyjnie używanych punktów widzenia stanie się niepewne, droga zatraci się w ciemnościach" (tamże). Ale ów stan rozchwiania nauki nie oznacza jej upadku, lecz postęp: „światło wielkich problemów kulturowych posuwa się dalej” (tamże). Ów postęp dokonuje się dzięki problematyzacji założeń, jest postępem świadomości, co Weber oddał słowami poety: „niebo nade mna, a pode mna fale” (tamże). Ale nieco wcześniej autor wyraża jednak pesymizm. Nie dotyczy on już poznania, lecz wartościowania, stanowiącego drugi niezbywalny element ludzkiej egzystencji: „konkretny kształt odniesienia do wartości pozostaje zatem 
płynny, podlega zmianie ciagnącej się ku ciemnej przyszłości ludzkiej kultury” (1988b: 213). Pesymizm Webera budzi fakt, że ilekroć wartościujemy, zakładamy, że wiemy, co jest dobre, zakładamy, że dokonujemy właściwego wyboru wartości. Obiektywność samego wyboru jest wszakże złudzeniem i jedynie usilne trzymanie się drogi poznania może nam to uświadomić.

Weber przeciwstawia zatem w swych tekstach metodologicznych dwie drogi: drogę wartościowania i drogę poznania. Sądzę, że ich analiza może pomóc uniknąć zasadniczych problemów interpretacyjnych, na jakie narazić może czytelników Webera przeciwstawianie sobie koncepcji Werturteilsfreiheit $\mathrm{i}$ Wertbęiehung. Najbardziej oczywisty problem polega na tym, że teza, iż ilekroć poznajemy, tylekroć wartościujemy, pozostaje w sprzeczności z postulatem, by nigdy nie wartościować w ramach działalności poznawczej. Jak jednak widzieliśmy, proces poznawczy i wartościowanie to złożone procesy, wielorako ze sobą powiązane. Werturteilsfreiheit oraz Wertbeqiehung to jedynie pewne cechy tych procesów i dlatego tak ważne jest zrozumienie ich funkcji.

Zreasumujmy zatem wnioski z dotychczasowej rekonstrukcji procesu poznania. Rozpoczyna się on od skierowania uwagi na określone zjawiska. Już w tej fazie podmiot dokonuje selekcji materiału ze względu na wartości, na które jest ukierunkowany. To samo odniesienie do wartości, które inicjuje proces poznawczy (Wertbęiebung1), sprawia również, że sfera zjawiskowa nie jest interesująca sama w sobie, a jedynie jako element działania, na przykład obiekt lub cielesny wymiar działania. Samo działanie okazuje się jednak również syntezą elementów, której zasadą jest orientacja na cel, motyw. Jedność działania ukazuje się nam w wyniku rozumienia - odniesienia własnych wartości, danych w bezpośrednim przeżyciu, do zachowań innych ludzi. Jak pamiętamy, motyw może być traktowany jako przyczyna działania. Jego zrozumienie może więc służyć przyczynowemu wyjaśnieniu działań własnych lub cudzych, ale może być też sam traktowany jako skutek oddziaływania interesów, a ostatecznie wartości. Powiązania między motywem, interesami i wartościami ujawniaja prawa, które socjolog może sformułować za pomoca indukcyjnego wnioskowania z faktów. Budowę praw można określić jako druga fazę poznania (nomologiczna). Wiedza nomologiczna sama może być „rozumiana”, jeśli poszczególne przyczyny i skutki, które wyodrębnia, mają „znaczenie kulturowe”, a więc są istotne jako elementy ludzkiej rzeczywistości. Uświadomienie sobie odniesienia do wartości danego w ,znaczeniu kulturowym” rozpoczyna trzecią fazę poznania, którą nazwać można właściwym „odniesieniem do wartości” (Wertbęiehung2). Jej zasadniczą funkcją jest nie tyle wspomniane wyodrębnienie znaczenia kulturowego w badanej rzeczywistości, lecz jego systematyczna 
artykulacja w postaci typu idealnego. Przesłanką tej artykulacji jest z kolei uzyskanie dystansu wobec żywej idei kulturowej przez przekształcenie jej z założenia w przedmiot badawczy. Ów moment dystansu należy odróżnić od „uprzedmiotowienia” w sensie wyzucia świata z wartości. Ten ostatni sens miał na myśli Theodor Adorno (1968|2003: 134), widząc w Weberowskich „wartościach” pochodną „wartości” ekonomicznych. Przeciwko takiej interpretacji świadczy jednak nie tylko fakt, że Weber świadomy był historii ekonomicznej idei „wartości” (1988b: 196), ale też to, że odniesione do wartości typy idealne stanowią formę dystansowania się wobec wartości kulturowych w imię obiektywności odniesienia do dobra (zewnętrznej miary człowieczeństwa). Weber ceni umiejętność nabierania dystansu do tego stopnia, że jako wartościowe dla nauki uważa osobiście obce mu politycznie, anarchizujące $\mathrm{i}$ kontestacyjne punkty widzenia:

Anarchista może być z pewnością dobrym znawca prawa. A jeśli nim jest, to właśnie ów punkt archimedejski, spoza kręgu oczywistych dla nas konwencji i założeń, ten punkt, w którym umiejscawia go jego obiektywne przekonanie (o ile tylko jest szczere), może sprawić, że w podstawowych poglądach zwyczajowej nauki prawa rozpozna on problematykę, która umyka tym, co te poglądy uważają za aż nadto oczywiste. Bowiem najbardziej radykalne wattpienie jest ojcem poznania. (1988c: 496)

Nawet najdalej idący konsens uczonych czy pogląd nigdy niepodważany przez ludzi danej kultury nie jest, według Webera, racją zaprzestania poszukiwań poznawczych i problematyzacji istniejącej wiedzy. Oznacza to, że proces poznania nie ma kresu i nigdy nie będzie mógł dostarczyć ważnych norm postępowania. O tym, jak bardzo odmiennie bywa dziś rozumiane zadanie nauki, zwłaszcza socjologii, świadczyć mogą słowa Michaela Burawoya, przewodniczącego Amerykańskiego Towarzystwa Socjologicznego: „Profesjonalna nauka może się rozwijać tylko wtedy, kiedy nie kwestionuje swoich zasad, kiedy nie zastanawia się nad swoimi podstawami” (Luczewski 2011: 212). Jak na ironię, to właśnie socjologia niebojąca się wartościowań chce odebrać ludziom odwagę mądrości, ale jest to konsekwencja w pełni zrozumiała, wszak wartościowania mają to do siebie, że nie są zdolne do kwestionowania własnych założeń. Tymczasem Weber podkreśla niezaspokojenie poznawczego interesu nauki. Czyni to również w dyskusji z Gustavem Schmollerem, który zdaje się zadowalać prawdami uznawanymi uniwersalnie - przez wszystkich ludzi. „Specyficzną funkcją nauki wydaje 
mi się coś wręcz przeciwnego - pisze Weber - a mianowicie to, że konwencjonalna oczywistość staje się dla niej problemem" (1988c: 502).

Chociaż sam typ idealny jest problematyzacją danego wycinka rzeczywistości, to jak widać z zacytowanych właśnie stwierdzeń Webera, służy on przezwyciężeniu samego siebie. Dzieje się to przeważnie przez uzyskanie nowej wiedzy, komplikującej posiadany dotąd obraz świata. Zysk poznawczy z nowej wiedzy może polegać jednak nie tylko na rozszerzeniu, lecz także na pogłębieniu obrazu, a więc na tym, że typ idealny ujawnia względność założeń podmiotów. Problematyzacja założeń każe poszukiwać założeń bardziej fundamentalnych, wartości ostatecznych. Ich odnalezienie każe z kolei postawić nowe problemy, przekierunkować optykę zgodnie ze słowami kończącymi Die Objektivität sozialwissenschaftlicher und sozialpolitischer Erkenntnis. Nauka, która odnajduje nowe ostateczne założenia, zyskuje nowe światło, które rzuca na wcześniej znane fakty i teorie, „spogląda z wyżyn myśli na strumień tego, co się dzieje” (1988b: 214).

Każdy z wymienionych etapów poznania - czyli refleksja nad działaniem, tworzenie wiedzy nomologicznej, świadome odniesienie do wartości oraz refleksja nad założeniami - charakteryzuje się specyficzną orientacja poznawcza. Na pierwszym etapie jest to stopniowe pogłębianie wiedzy, dookreślanie interesu poznawczego. $\mathrm{Na}$ drugim etapie wiedza nomologiczna jest zdobywana przez rozumienie, indukcję i dedukcję. Na etapie trzecim dochodzi do selekcji i problematyzacji nowych obszarów poznawczych. Proces problematyzacji ukierunkowuje również etap czwarty, w którym dochodzi dodatkowo do sformułowania wyników dotychczasowego wysiłku. Zarysowany tu cykl jest otwarty, to znaczy końcowa problematyzacja może stanowić początek dalszego pogłębiania refleksji nad działaniem. Cykliczność procesu poznawczego pozwala więc wyróżnić w nim bardziej ogólne fazy teorii i praktyki, zarazem wiążąc je ze soba.

Spróbujmy zestawić uzyskany właśnie obraz poznania z wartościowaniem. Rozpoczyna się ono w miejscu, w którym poznanie się kończy, a więc od ostatecznych założeń. To właśnie fakt, że je mamy, sprawia, że jesteśmy skłonni orzekać, co jest dobre lub złe, że czegoś pragniemy lub że pewnych pragnień się wyrzekamy. W odróżnieniu od ostatecznych wartości formułowanych $\mathrm{w}$ procesie poznania te, które sa podstawa wartościowań, nie są z reguły wyeksplikowane, lecz są przedmiotem wiary. Sam akt wiary pozostaje zwykle ukryty. Fakt ten jest istotny, ponieważ właśnie z uwagi na nieświadomość swych wartości, ludzie skłonni są uważać je bądź za „naturalne”, bądź możliwe do uzasadnienia na podstawie faktów empirycznych. Tymczasem owe fakty często zawierają już wartościowania, choćby pod postacią idei historycznych koniecznych do opisu zjawisk. 
Nie oznacza to wszakże, iż wyznawane wartości nigdy się nie ujawniaja ani nie ukazują swej problematyczności. Dzieje się tak zwłaszcza wtedy, gdy dochodzi do kolizji różnych wartości, głównie w stosunkach międzyosobowych bądź pomiędzy różnymi grupami społecznymi. W tekście Der Sinn der „Wertfreibeit” der soziologischen und ökonomischen Wissenschaften (1988c) Weber podkreśla odrębność imperatywów etycznych od różnych „wartości kulturowych”, które moga być zgodne lub niezgodne z maksyma postępowania. Podkreśla przy tym, że Kantowska etyka imperatywna zawiera zalecenia, które nie są czysto formalne, lecz mają praktyczną treść. Realizacja wartości kulturowych może prowadzić do konieczności wzięcia na siebie „odpowiedzialności etycznej” (1988c: 504). Od kogoś, kto podejmuje się wartościowania, można zatem oczekiwać, że będzie starał się uświadomić sobie wartości, w które wierzy, i porówna je z wartościami konkurencyjnymi. Wyraźnie wynika to z omawianego wcześniej postulatu „konfrontacji” różnych wartości, zwłaszcza własnych (1988b: 156-157). Pozwala to na dokonanie świadomego wyboru własnych wartości i sprawdzenia własnego systemu wartości pod względem jego niesprzeczności. Tę pierwszą fazę wartościowania można określić jako fazę „uświadomienia”. Faza druga polega na dedukcji konsekwencji, jakie wynikaja z realizacji ustalonego wcześniej systemu wartości. Dedukcja ta możliwa jest jednak jedynie pod warunkiem znajomości praw dotyczących skutków danych działań. Ta z kolei wymaga wcześniejszej procedury indukcyjnej, a więc uzyskania wiedzy nomologicznej dotyczącej skuteczności środków, które dana osoba chce zastosować oraz ewentualnych skutków ubocznych zastosowania tych środków (kosztów). Ten drugi etap możemy w całości określić jako fazę uzyskiwania wiedzy nomologicznej. Prowadzi ona do fazy trzeciej, w której podmiot modyfikuje swe aksjomaty w obliczu posiadanej wiedzy. Dopiero w tej fazie podejmuje ostateczną decyzję w sprawie wyboru wartości. Jest to faza „kreatywna”, w której dzięki uzyskanej wiedzy podmiot może być umotywowany (w przypadku wzorcowym) do „odejścia od swej wiary”. Wreszcie w ostatniej fazie podmiot podejmuje decyzję i się jej wewnętrznie podporządkowuje, uznaje decyzję za podjętą, by z przekonaniem poświęcić się swojej sprawie. Jest to faza „podporządkowania”.

Podobnie jak w wypadku faz poznania w procesie wartościowania możemy odróżnić specyficzne formy orientacji podmiotu w poszczególnych fazach. Na początku jest to orientacja na świat zewnętrzny. Warto podkreślić, że wiara w wartości nie ukierunkowuje podmiotu na same te wartości, lecz na potencjalne obiekty działania. Wiara jest pod tym względem przeciwieństwem refleksyjności rodzącej interesy poznawcze. Druga faza jest właściwie tożsama $\mathrm{z}$ fazą uzyskiwania wiedzy nomologicznej 
w procesie poznania, obejmując dedukcję, indukcję i rozumienie, choć warto zauważyć, że rola rozumienia znacznie w nim spada, ponieważ w określeniu możliwych skutków działania rozumienie jest znacznie mniej istotne niż wykorzystanie praw przyczynowych. W roli selekcyjnej zastępuje je właściwie wyjściowy akt wiary i droga poznawcza wyznaczona przez kolizje wartości. W fazie trzeciej podmiot orientuje się na uzasadnienie swej decyzji. Wtedy to jest zmuszony uzgodnić swój akt wiary z posiadana wiedzą. Jest to właśnie moment napięcia między etyką sumienia a etyką odpowiedzialności. Ta pierwsza określa postawę braku gotowości na modyfikację swych aksjomatów, druga zaś postawę (względnej) otwartości na wiedzę. Ostatnia faza charakteryzuje się reorientacja podmiotu na działanie, oznacza ponowny zwrot na zewnattrz po refleksji wywołanej pojawieniem się wyzwań dla wyjściowego systemu wartości.

Proces wartościowania można ogólnie określić jako zamknięty. Końcowe zwrócenie się w stronę świata, podporządkowanie się własnemu wyznaniu wiary nie jest zarazem punktem wyjścia, aktem wiary, który uruchomił cały proces wartościowania, lecz jego dopełnieniem. Ponadto akt wiary jest aktem pewności, który wprawdzie nie pozostaje zapewne nigdy zupełnie niewzruszony, ale konstytuuje człowieka, pragnącego upewnić się w swej postawie, umocnić w sile swych założeń. Wiedza, której wymaga proces wartościowania, jest z kolei wynikiem niekompletnego procesu poznania, obejmuje wszak tylko zastosowanie praw przyczynowych - w tym sensie wartościowanie jest poznawczo „płytkie”. Kreatywność wartościowania, o ile dojdzie do głosu, wynika tylko z pojawienia się w wartościowaniu „fazy poznawczej” i jest narażone na opór sumienia. Wreszcie końcowy akt podporządkowania, jakkolwiek nieunikniony w życiu każdego człowieka i z tego względu pozytywnie oceniany przez Webera (Hinwendung zur Sache, np. 1988c: 494; 1988d: 591 a zwłaszcza w słynnym fragmencie o ,wymaganiu dnia" 1988d: 612-613; w odniesieniu do polityków 1992: 62), nie pozwala człowiekowi poszukiwać upragnionego dobra, lecz w gruncie rzeczy stanowi rodzaj autoiluzji, obrony własnej egzystencji przez utożsamienie się z założeniami, w których złożyło się swe nadzieje. Końcowe wezwanie wypowiedziane w Wissenschaft als Beruf można interpretować co najwyżej jako stanowisko, że napięcie między koniecznością a niemożliwością dobra nie zwalnia z obowiązku działania.

Zasadnicza różnica między oboma opisanymi wyżej procesami dotyczy jednak samego stosunku do wartości, a w konsekwencji do ostatecznych założeń, które człowiek przyjmuje w swoim życiu czy w danym typie działalności, na przykład w sferze zawodowej. Poznanie jest w ujęciu Webera procesem, w którym osoba, wychodząca początkowo z określonych 
założeń, rozpoznaje stopniowo ich względność i błędność, aby zacząć zadawać pytanie o ich pochodzenie i sens. Ta różnica kierunku myślenia, a więc między myśleniem „z perspektywy założeń” i „w stronę założeń” pozwala zinterpretować zasadę wolności od sądów wartościujących jako postulat odwracania kierunku myślenia, każdorazowego demaskowania założeń, które najczęściej nieświadomie kierują ludzi w stronę określonych sposobów postępowania i kształtują trwałe typy mentalności, w których wiara staje się ostoją własnego istnienia. Weber proponuje nam wyzwolenie się z tej wiary, ale nie w imię własnej korzyści, przemijających ideałów, lecz w imię obiektywnego dobra, którego poszukiwanie jest specyficznie ludzkim sposobem istnienia. Człowiek, który z tej drogi schodzi w imię wartości, uznanych za ostateczne na mocy swej decyzji, naraża się nie tylko na konflikty z innymi, ale też na to, że jego egzystencja stanie się ucieleśnieniem błędnych myśli.

W stosunku do proponowanej tu interpretacji może paść zarzut, że dotyczy ona dwóch wyabstrahowanych procesów, które same sa typami idealnymi, a realnie są nieoddzielne i nie przebiegaja zgodnie w opisanym porządku. Zarzut ten wydaje mi się w dużej mierze słuszny. Nakreślone typy drogi człowieka sa w istocie typami idealnymi mającymi unaocznić dwa przeciwstawne sposoby ustosunkowywania się człowieka do swego świata (w tym sensie dwie odmiany Einfüblung). Weberowskie idee można jednak wykorzystać do zarysowania drogi bliższej realnemu ludzkiemu życiu i wskazać momenty, w których wolność od sądów wartościujących odgrywa w niej rolę „poznawczego przekierunkowania” człowieka.

Głównym wątkiem pierwszego omawianego tu tekstu metodologicznego Webera na temat Roschera i Kniesa była możliwość uzgodnienia deterministycznej wizji świata rządzonego przez prawa z wizją wolnego człowieka kształtującego rzeczywistość kultury. Problem ten doprowadził Webera do rozważań na temat możliwości poznania wartości ostatecznych. Okazało się, że nauki społeczne mogą o wartościach powiedzieć bardzo wiele - moga je opisywać, porównywać, badać ich konsekwencje i przemiany. Za sprawą wiedzy, której dostarczają, mogą nawet pomóc człowiekowi w dokonaniu wyboru wartości, ale samego wyboru dokonać nie moga, człowiek musi pozostać samotnym poszukiwaczem dobra. Spróbujmy zatem zrekonstruować na podstawie omawianych tekstów etapy, które człowiek musi pokonać na drodze poszukiwania dobra, korzystając z wartości kulturowych.

Pierwszy etap można scharakteryzować jako utożsamienie dobra z korzyścią własna. Wskazują na to rozważania Webera o związku między wyborem wartości a przynależnością klasową i stanową. Orientacja na bliski krag społeczny silnie ukierunkowuje ludzkie wysiłki na samozachowanie 
siebie i swojej grupy. Toteż wyznacznikiem wyznawanych wartości staja się interesy, a punktem odniesienia staje się „Ja”. „Ja” jest miarą słuszności podejmowanych decyzji, miarą wartości, które samo stanowi. Jak pamiętamy, Weber dostrzega jednak ograniczoność zasady samozachowania, co uwidacznia, nie tylko krytykując funkcjonalizm w artykule na temat Roschera i Kniesa, lecz także w określeniu wartości jako zaleceń, które są nie tylko zrozumiałe, ale też potencjalnie akceptowalne dla innych. Właśnie z tej tendencji do uniwersalizacji wyrasta praktyka tworzenia wartości na drodze syntezy - godzenia ideałów różnych grup społecznych i kultur. Weber zdecydowanie przeciwstawia się tej strategii. Synteza nie czyni bowiem wartości ani o włos bardziej uzasadnionymi. Słuszności może im dostarczyć jedynie niezależny sprawdzian rozumu, a nie polityczne porozumienie. Decyzja o poszukiwaniu wartości oznacza specyficznie filozoficzny zwrot w drodze poznawczej człowieka, rozpoznanie swego metafizycznego powołania, które Weber wnikliwie dostrzega w naukach różnych religii światowych. W perspektywie uniwersalno-historycznej można go również interpretować jako zwrot „epoki osiowej” (podobnie Hans Joas, patrz wywiad Kaczmarczyka i Roby 2012: 186).

Poszukiwanie dobra w wartościach kulturowych prowadzi wszak początkowo do rozczarowania - do odkrycia własnej niewiedzy o wartościach. Poszukujący musi stanąć twarzą w twarz z własnym aktem wiary, dostrzec nieadekwatność teorii naukowych do kwestii wyboru wartości. To rozczarowanie nie zwalnia jednak człowieka z obowiązku poszukiwania dobra, na nim przecież zasadza się jego istnienie. Tak można, jak sądzę, interpretować dwa pozornie przeciwstawne sobie obowiązki sformułowane przez Webera - „stanięcia po stronie swoich wartości” (für eigene Werte eintreten) a zarazem gromadzenia „wiedzy o faktach” (1988b: 155). Stanięcie po stronie swoich wartości oznacza nic innego jak demaskowanie założeń przez badanie ich konsekwencji i kontekstu. Stanięcie po stronie wartości to ich sprawdzanie. Ten właśnie obowiązek, wynikający, podkreślmy, z samej natury człowieczeństwa jako bytu, prowadzi do konfrontacji z wartościami Innego, do próby zrozumienia jego wartości i postawienia pytania: co oznaczają one z mojej perspektywy, w mojej specyficznej sytuacji życiowej?

Intersubiektywne badanie i sprawdzanie wartości wymaga wolności od sądów wartościujących - wierności obranej wcześniej drodze myślenia „ku założeniom". Dzięki tej zasadzie możliwe jest nie tylko poprawne i wiarygodne poznanie, ale też powstanie wspólnoty uczonych, którą łączą potrzeby poznawcze i dążenie do dobra, a nie interesy stanowe. Wolność od sądów wartościujących kształtuje społeczność, która nie jest nękana konfliktami 
wynikającymi z prób zyskania łatwego prestiżu przez fałszywych proroków, przekonanych, że posiedli już wiedzę o dobru i pragną uwiarygodnić to w najlepszym razie wynikami swych prac badawczych, a w najgorszym tytułami i stanowiskami naukowymi (1988c: 492-493). Solidarność, która spaja środowisko naukowe dzięki przestrzeganiu zasady wolności od sądów wartościujących, rodzi jednak w pewnym sensie zagrożenie, któremu chce zapobiegać. Uczeni podejmujący badania na dany temat, a więc kierujący się określonymi interesami poznawczymi, nie są nigdy w stanie wyzbyć się swych wartości, w całym swym życiu i każdej działalności pozostaja odniesieni do wartości, a solidarność ich środowiska zwiększa jeszcze siłę i wpływ tego odniesienia w tej mierze, w jakiej uczeni tworzą zamknięte szkoły, wyspecjalizowane instytuty naukowe, waskie dyscypliny naukowe i popadają w jednostronność wynikająca $z$ przynależności do danego fachu (Ressortpatriotismus). Zwiększa się wtedy ryzyko absolutyzacji własnych założeń i ulegania specyficznie pojętej korzyści własnej, która przecież stanowiła wyjściowy problem drogi poznania wartości. Czyżby nauka była skazana na to, czego najbardziej chce uniknąć?

Wkład Webera do dyskusji nad postawionym wyżej pytaniem polega przede wszystkim na opracowanej przez niego strategii radzenia sobie z „odniesieniem do wartości”. Polega na wykorzystaniu Wertbęiebung do poznania wartości. Ów zysk poznawczy możliwy jest wszakże tylko pod warunkiem przestrzegania zasady Werturteilsfreiheit. W przeciwnym razie odniesienie do wartości nie mogłoby stać się samo przedmiotem refleksji. Spróbujmy więc prześledzić tu krótko, na podstawie tego, co zostało powiedziane w poprzednich częściach artykułu, w jaki sposób odniesienie do wartości ,ujawnia” się przed badaczem i pozwala mu na poznanie wartości (rysunek 1).

Pierwszym przejawem odniesienia do wartości w pracy badawczej jest postawienie problemu, wyodrębnienie elementów rzeczywistości, które się wiążą z jakąs ludzka potrzebą czy ideałem, a następnie spojrzenie na nie z indywidualnej i w końcu specyficznie ludzkiej perspektywy. Problem istnieje o tyle, o ile istnieje interes poznawczy, który czyni rzeczywistość „naszą". Konsekwencja postawienia problemu jest wyodrębnienie przedmiotu badawczego, czyli tych aspektów rzeczywistości, które jakoś wiążą się z dostrzeżonym (odczuwanym) problemem. Przedmioty prowadzą uczonego do motywów, jakie ludzie wiążą z interesującymi go aspektami obiektu. Motywy istnieja zaś o tyle i o tyle moga być przedmiotem systematycznych badań, o ile kryje się za nimi znaczenie kulturowe, wartości, które strukturyzują świat ludzkiego doświadczenia. Konsekwencją rozpoznania znaczenia kulturowego w jego historycznych powiązaniach może być 


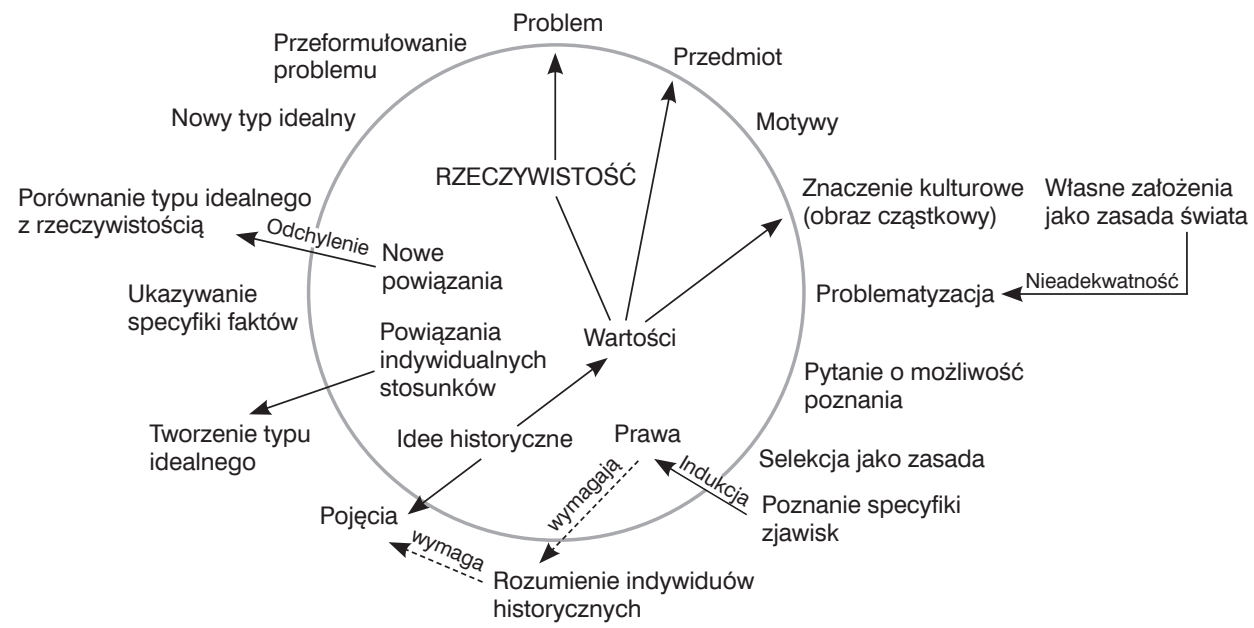

Rysunek 1. Schemat odniesienia do wartości (Wertbęiehung)

dostrzeżenie czastkowości obrazu, jakim zajmuje się badacz. Jest to także moment, w którym pojawia się zagrożenie absolutyzacji owego wycinka rzeczywistości i uczynienia jego praw zasadami całej rzeczywistości (taki charakter maja marksizm, a także teorie rasowe). Stosunkowo łatwo można jednak zorientować się, że taka absolutyzacja jest błędna, wskazuje na to bowiem empiryczna nieadekwatność teorii zbudowanych na jednostronnych czy zbyt wąskich założeniach (ponownie przykładem - marksizm). Prawidłowe postępowanie badacza, który dostrzega cząstkowość swego obrazu świata, jest problematyzacja tego obrazu i poszukiwanie nowych elementów poza dotychczas badanym obszarem. Ponieważ jednak taka praca nigdy nie będzie miała końca, teoria nauki musi odpowiedzieć w tym właśnie miejscu na pytanie: Jak możliwe jest poznanie? Dotychczas przebyta droga wskazuje jednoznacznie na to, że jest ono możliwe jedynie dzięki selekcji, selekcja jest wręcz zasada poznania. Co jest jednak kryterium samej selekcji? Aby się tego dowiedzieć, trzeba przyjrzeć się jej przebiegowi. Rozpoczyna się od poznania rzeczywistości w postaci wyjątkowości (Eigenart) jej elementów. Można je zrozumieć (jako elementy rzeczywistości specyficznie ludzkiej) jedynie pod warunkiem znajomości ich przyczyn i skutków. Tego dostarcza procedura indukcji prowadzaca do formułowania praw nauki. Rozumienie okazuje się jednak wymagać czegoś jeszcze, czegoś, co sprawia, że nie pozostaje tylko idiosynkratycznym ,wczuciem się” - wymaga pojęć. Nie wywodzą się one z praw, które mają charakter czysto formalny. Uczeni czerpią pojęcia z samej rzeczywistości - z idei historycznych, które obrastaja we własne sieci znaczeń i powiązań. Ponieważ owe idee odnosza się do wartości, to takież odniesienie jest też udziałem pojęć naukowych. 
Rozpoznanie tego odniesienia (właściwego odniesienia do wartości, które nazwaliśmy Wertbeziehung2) stanowi inspirację do tworzenia typów idealnych, przez które uczony dystansuje się wobec własnego odniesienia do wartości. Zarazem dokonuje też świadomej selekcji pojedynczych stosunków, których synteza jest typ idealny. Pojęcie typu idealnego jest u Webera nie tylko propozycją metodologiczna, lecz również obrazem świadomego odtwarzania przez uczonego typu procesu, który zachodził w nim od początku jego ludzkiego istnienia - odnoszenia wartości do świata. Różnica między procesem nieświadomym a świadomym polega tu na tym, że dzięki świadomości „Ja" ustępuje z pozycji centrum rzeczywistości - podmiotu, który tworzy wartości i je stosuje. Rzeczywistość niechybnie wykazuje odchylenia od typu idealnego, co pozwala na formułowanie nowych typów idealnych i stawianie nowych problemów naukowych. W ten właśnie sposób „odkrywanie” (przede wszystkim u samego siebie) odniesienia do wartości pozwala na poznanie wartości także w sensie przemiany własnego systemu wartości, wbrew wcześniejszej obiekcji, iż poznanie w dziedzinie nauk o kulturze w ogóle nie jest możliwe, a więc też nie może pomóc człowiekowi poszukującemu dobra.

Powyższa konstatacja mogłaby właściwie stanowić zakończenie niniejszego tekstu, ponieważ zamyka interpretację Weberowskiej zasady Werturteilsfreiheit. Warto jednak wspomnieć na koniec, że zasada ta zyskała sobie sławę przede wszystkim jako podstawa kodeksu etycznego świata uczonych, rodzaj praktycznej bariery chroniącej świat akademicki przed wpływami polityki, religii i innych oddziaływań obcych systematycznej pracy naukowej kierującej się dążeniem do prawdy. W tym sensie zasada ta może łatwo ulec sama ,uprzedmiotowieniu” jako zasada relacji między społecznym systemem nauki a innymi systemami społecznymi. Ta Luhmannowska interpretacja (2012: 100), jakkolwiek może być owocna dla samej teorii systemów, nie jest jednak w żaden sposób związana z Weberowską Werturteilsfreiheit, nie dotyczy bowiem człowieka stojącego przed problemem wyboru wartości. Luhmann podejmuje wątek selekcji poznawczej i podobnie jak Weber pyta o jej zasadę, w miejsce wartości wprowadza jednak systemy, które z kolei same stają się u niego zasada rzeczywistości. Za sprawą tego uprzedmiotowienia to właśnie do Luhmanna raczej niż do Webera stosuje się wspomniana wcześniej krytyka ze strony Theodora Adorno. Weberowska zasada niewatpliwie może być odnoszona do organizacji uniwersytetów i może być wspierana argumentami dotyczącymi jakości współpracy naukowej (takich argumentów dostarcza sam Weber), ale nie muszą to być argumenty jedyne i wcale nie zawsze muszą znaleźć zastosowania (1988c: 491). Weber nie formułuje swej zasady kategorycznie, lecz pisze, że jej przestrzeganie na uniwersytetach 
powinno zależeć od zadań, jakie uniwersytet stawia sobie w swym statucie (tamże). Jeśli jednak jednym $z$ tych zadań jest pomoc studentom w ich dążeniach poznawczych, to z Weberowskiej zasady wynikają dla uczelni dwie podstawowe maksymy. Po pierwsze, jest to postulat wyrabiania w studentach umiejętności dystansowania się wobec własnych założeń poznawczych (nauczanie krytycyzmu wobec samego siebie), po drugie zaś, przyuczania ich do podporząd kowywania się swemu zadaniu poznawczemu. Podporządkowanie oznacza ,stawianie własnej osoby za pracą rzeczowa” i powstrzymywanie własnych uprzedzeń w interpretowaniu i wyjaśnianiu naukowym (1988c: 493). Niekiedy wymaga to „płynięcia pod prąd" (1988c: 540), Weber domaga się więc od uniwersytetu kształtowania w studentach nade wszystko silnych osobowości, odpornych na wpływy fałszywych proroków i zdolnych samodzielnie kierować swym poznaniem oraz oceniać jego postępy. Sądzę, że umiejętność ta jest dziś szczególnie potrzebna, uczeni zdają się bowiem tracić zdolność oceny własnej działalności, a nawet świadomość jej sensu. Jest to widoczne w powszechnej wierze w oceny „zewnętrzne”, „zobiektywizowane”, w „mierzalne” kryteria osiagnięć. Brak orientacji co do miejsca, w jakim się znajdujemy na indywidualnej i zbiorowej drodze poznania, powoduje biurokratyzacje i komercjalizację nauki a nawet jej inkorporację do instytucji, których cele sa wyraźne, miara skuteczności jasna, a wartości niekwestionowane. Wbrew temu, co sugeruje Gouldner (1984: 42), Weber nie jest obrońca nauki „bezdusznych techników” czy przygotowywania studentów do tego, by byli „używani” przez innych (tamże), lecz wręcz przeciwnie - pragnie powrotu do uniwersytetu kształtującego silną osobowość, poszukującego wiedzy płynącej z samego pragnienia bycia człowiekiem i świadomości swego powołania. Artykuł Gouldnera, który nie odnosi się do żadnego tekstu Webera, stanowi właściwie całkowite odwrócenie sensu nauk niemieckiego socjologa. Z naszych rozważań wynika bowiem także, iż wbrew temu, co pisze Gouldner (1984: 41), Weber nie uważał za autentyczne tych tylko wartości, którym przysługuje ,intuicyjna pewność”, ani tym bardziej nie opowiadał się za wiarą w rzekomej walce wiary z rozumem. Być może do podobnych interpretacji zawiodła Gouldnera ta sama socjologia wiedzy, która kazała mu widzieć w Platonie władczego inżyniera społecznego „teatru”, którego aktorzy mieli być marionetkami w rękach rozczarowanego filozofa, a nie samodzielnie dążyć do zrozumienia sensu swego istnienia (Gouldner 1965: 382-383).

Odpowiedź na pytanie o sens nauki możliwa jest tylko pod warunkiem, że znamy sens życia jako takiego; że potrafimy rozstrzygnąć spory między różnymi porządkami wartości, które próbuja zyskać nad nami władzę. 
Ta walka jest nadal widoczna na każdym kroku i nie jesteśmy w stanie uchylić się od naszego indywidualnego problemu egzystencjalnego, nawet jeśli zbagatelizujemy tę walkę, czy zdamy się na tradycyjne odpowiedzi. W świecie wymagającym szybkich decyzji takie strategie wydają się coraz mniej obiecujące. Odpowiedzią na problem, przed którym stoi każdy z nas i który Weber ma odwagę wyartykułować w całym jego nowoczesnym dramatyzmie, może być tylko zdystansowanie się wobec własnych założeń, sprawienie, by życie nie „polegało na sobie samym” (1988d: 608)i by własne „Ja" nie stanowiło ostatecznej miary wartości. Drogę do samoświadomego poznania otworzyć dziś może uniwersytet, który właśnie dzięki zasadzie wolności od sądów wartościujących sprawi, że „z życia publicznego nie znikną ostateczne i najbardziej wysublimowane wartości” (1988d: 612).

Bibliografia:

/// Abell P. 1975. Modele w socjologii, tłum. M. Tabin, PWN, Warszawa.

/// Adorno T. 2003. Einleitung in die Soziologie, Suhrkamp, Frankfurt am Main.

/// Alexander J. 1995. General Theory in the Postpositivist Mode: The Epistemological Dilemma' and the Search for Present Reason, [w:] Fin de Siècle Social Theory, J. Alexander, Verso, London, s. 90-127.

/// Boudon R. 2001. The Origin of Values. Sociology and Philosophy of Beliefs, Transaction, London.

/// Caplovitz D. 1967. The Poor Pay More, Collier-Macmillan, London.

/// Gouldner A. 1965. Enter Plato. Classical Greece and the Origins of Social Theory, Basic Books, New York.

/// Gouldner A. 1984. Anty-Minotaur cryli mit socjologii wolnej od wartości, tłum. E. Morawska, [w:] Krysys i schizma. Antyscjentystyczne tendencje w socjologii wspótczesnej, t. I, red. E. Mokrzycki, PIW, Warszawa, s. 13-43.

/// Habermas J. 1968. Erkenntnis und Interesse, Suhrkamp, Frankfurt am Main.

/// Joas H. 2009. Powstawanie wartości, tłum. M. Kaczmarczyk, Oficyna Naukowa, Warszawa.

/// Kaczmarczyk M., Roby E. 2012. Intersubiektywność, uniwersalizm i dialog (wywiad z Hansem Joasem), „Studia Socjologiczne” 2012, nr 1, s. 183-196. /// Kaczmarczyk M. 2010. Niepostuszeństwo obywatelskie a pojecie prawa, Oficyna Naukowa, Warszawa. 
// / Käßler D. 1997. Soziologie als Berufung. Bausteine einer selbstbewußten Soziologie, Westdeutscher Verlag, Opladen.

/// Luhmann N. 2012. Systemy społeczne. Zarys ogólnej teorii, tłum. M. Kaczmarczyk, NOMOS, Kraków.

/// Luczewski M. 2011. Socjologia anioła. Z Michaelem Burowoyem rozmawia Michat Łucrewski, „Stan Rzeczy” 2011, nr 1, s. 209-213.

// / Mackie J.L. 1965. Causes and conditions, „American Philosophical Quarterly" 1965, t. 24, s. 245-264.

/// Marrou H-I. 2011. O poznaniu bistorycznym, tłum. H. Łaszkiewicz, Wydawnictwo Marek Derewiecki, Kęty.

/// Parsons T. 1968. The Structure of Social Action, t. I i II, Free Press, New York.

/// Schluchter W. 1979. Die Entwicklung des okezidentalen Rationalismus, J.C.B. Mohr, Tübingen.

/// Schluchter W. 1991. Religion und Lebensfübrung. Studien zu Max Webers Kultur- und Werttheorie, t. I, Suhrkamp, Frankfurt am Main.

/// Simmel G. 1989. Die Probleme der Geschichtsphilosophie, [w:] tenże, Aufsätze 1887-1890. Über sociale Arbeitsteilung. Die Probleme der Geschichtsphilosophie, Suhrkamp, Frankfurt am Main, s. 297-421.

/// Sztompka P. 1975. O problemie wartościowania w naukach spotecznych, „Studia Socjologiczne” 1975, nr 3, s. 93-129.

/// Topolski J. 1984. Metodologia historii, wyd. 3, PWN, Warszawa.

/// Weber M. 1958. Gesammelte politische Schriften, wyd. 2, J.C.B. Mohr, Tübingen.

/// Weber M. 1988a. Roscher und Knies und die logischen Probleme der historischen Nationalökonomie, [w:] tenże, Gesammelte Aufsätze zur Wissenschaftslehre, J.C.B. Mohr, Tübingen, s. 1-145.

/// Weber M. 1988b. Die Objektivität sozialwissenschaftlicher und sozialpolitischer Erkenntnis, [w:] tenże, Gesammelte Aufsätže zur Wissenschaftslehre, J.C.B. Mohr, Tübingen, s. 146-214.

/// Weber M. 1988c. Der Sinn der Wertfreiheit der soziologischen und ökonomischen Wissenschaften, [w:] tenże, Gesammelte Aufsätz̧e zur Wissenschaftslehre, J.C.B. Mohr, Tübingen, s. 489-540. 
/// Weber M. 1988d. Wissenschaft als Beruf, [w:] tenże, Gesammelte Aufsätze zur Wissenschaftslehre, J.C.B. Mohr, Tübingen, s. 582-613.

/// Weber M. 1992. Politik als Beruf, Philipp Reclam, Stuttgart.

\section{/// Abstrakt}

Sformułowany przez Maxa Webera, słynny postulat wolności od sądów wartościujących jest do dziś ważnym wyzwaniem dla socjologii, która zarazem pragnie zachować epistemiczną obiektywność oraz nie tracić swego krytycznego ostrza pozwalającego jej odgrywać inspirująca i mediująca rolę w debacie publicznej. W prezentowanym tekście autor proponuje interpretację tekstów Webera poświęconych temu problemowi i opowiada się za interpretacja, zgodnie z którą koncepcji Werturteilsfreibeit oraz Wertbeziebung nie należy traktować odrębnie czy też jako sprzecznych ze sobą, lecz raczej postrzegać postulat wolności od sądów wartościujących jako wynikający z idei odniesienia do wartości. Wedle propozycji autora Weber przedstawia w swych tekstach obraz ludzkiej drogi poznania, która stanowi odpowiedź na dylematy perspektyw wartościujących.

Słowa kluczowe:

wartości, wolność od wartości, Max Weber, Wertfreiheit, Werturteilsfreiheit, Wertbeziehung, socjologia krytyczna, socjologia wiedzy

\section{/// Abstract}

Max Webers' idea of value neutrality has been an important challenge for sociology. As a science of practical aspirations sociology has aimed to maintan a balance between epistemic objectivity and social criticism. The latter was hoped to provide public debate with inspiration and mediating social discourse. The author of the paper is advocating for an interpretation of Webers' relevant texts that would deny the apparent contadiction between the concepts of Wertfreiheit and Wertbeziehung, and view them as logically interrelated. He suggests that the idea of value neutrality, as formulated by Weber, follows from his concept of value reference. As claimed in the paper, in his texts Weber outlined a picture of the human way of cognition that may be interpreted as a response to the dilemmas of value-oriented points of view.

Keywords:

values, value neutrality, Max Weber, Werffreiheit, Werturteilsfreiheit, Wertbeziebung, critical sociology, sociology of knowledge 